\title{
Pathogenesis and new candidate treatments for infantile spasms and early life epileptic encephalopathies: a view from preclinical studies.
}

\author{
Aristea S. Galanopoulou ${ }^{1}$, Solomon L. Moshé ${ }^{1,2}$
}

${ }^{1}$ Saul R. Korey Department of Neurology, Dominick P. Purpura Department of Neuroscience, Laboratory of Developmental Epilepsy, Montefiore Medical Center, Albert Einstein College of Medicine, Bronx NY USA

${ }^{2}$ Department of Pediatrics, Montefiore Medical Center, Albert Einstein College of Medicine, Bronx NY USA

\section{Short Title: $\quad$ Animal models of early life epilepsy}

\begin{tabular}{|l|l|}
\hline Corresponding Author: & \\
Aristea S. Galanopoulou MD PhD & Solomon L. Moshé MD \\
Albert Einstein College of Medicine & Albert Einstein College of Medicine \\
1410 Pelham Parkway South & 1410 Pelham Parkway South \\
Kennedy Center Rm 306 & Kennedy Center Rm 316 \\
Bronx NY 10461, USA & Bronx NY 10461, USA \\
Tel: +1-718-430-3791 & Tel: +1-718-430-2464 \\
Fax: +1-718-430-8899 & Fax: +1-718-430-8899 \\
E-mail: aristea.galanopoulou@einstein.yu.edu & E-mail: solomon.moshe@ einstein.yu.edu \\
& \\
\hline
\end{tabular}




\begin{abstract}
Early onset and infantile epileptic encephalopathies (EIEEs) are usually associated with medically intractable or difficult to treat epileptic seizures and prominent cognitive, neurodevelopmental and behavioral consequences. EIEEs have numerous etiologies that contribute to the inter- and intra-syndromic phenotypic variability. Etiologies include structural and metabolic or genetic etiologies although a significant percentage is of unknown cause. The need to better understand their pathogenic mechanisms and identify better therapies has driven the development of animal models of EIEEs. Several rodent models of infantile spasms have emerged that recapitulate various aspects of the disease. The acute models manifest epileptic spasms after induction and include the NMDA rat model, the NMDA model with prior prenatal betamethasone or perinatal stress exposure, and the $\gamma$-butyrolactone induced spasms in a mouse model of Down syndrome. The chronic models include the tetrodotoxin rat model, the aristaless related homeobox X-linked (Arx) mouse models and the multiple-hit rat model of infantile spasms. We will discuss the main features and findings from these models on target mechanisms and emerging therapies. Genetic models have also provided interesting data on the pathogenesis of Dravet syndrome and proposed new therapies for testing. The genetic associations of many of the EIEEs have also been tested in rodent models as to their pathogenicity. Finally, several models have tested the impact of subclinical epileptiform discharges on brain function. The impact of these advances in animal modeling for therapy development will be discussed.
\end{abstract}

\title{
KEYWORDS
}

West syndrome, Dravet syndrome, mTOR, epilepsy, cognition, SUDEP, Arx, GABA, sodium channels, multiple-hit model, GABA, NMDA, tetrodotoxin. 


\section{INTRODUCTION}

Epileptic encephalopathies are a spectrum of syndromes with prominent cognitive or behavioral impairments that are beyond what is expected for the underlying pathologies and to which the epileptic activity is thought to contribute significantly (Berg et al. 2010). These are particularly prevalent in the early stages of life. The poor outcomes in both epilepsy severity and neurodevelopmental and behavioral measures and the limited treatment options render these conditions a priority in epilepsy research. Clinical studies have offered insight about possible pathomechanisms. However, the inherent difficulties in human experimentation, the small numbers of patients included in studies on rare diseases, the heterogeneity of syndromes such as West syndrome and infantile spasms (IS), the limited availability of human tissue from the critical stages of early disease development, and the multiple confounders that plague the comparisons across human patients limit the power of such studies.

Over the last years, with the advances of animal modeling and discoveries into the genetics of epileptic encephalopathies, a number of animal models have emerged. These animal models were designed to recapitulate specific aspects of the phenotype of human epilepsy syndromes, recreate specific pathologies or etiologies (genetic or acquired), or test the relevance of signaling pathways on the pathogenesis or treatment response. As a result, there are several animal models of West syndrome or IS, models of Dravet syndrome or of other early onset or infantile epileptic encephalopathies (EIEEs), and animal studies attempting to decipher the contribution of epileptic spikes in the cognitive and neurodevelopmental outcomes. Because there are numerous EIEEs, here we have specifically selected those for which animal models have been created that address the phenotype or genetic causes. We will discuss how human and animal studies have contributed to our understanding on the pathophysiology of these selected epileptic encephalopathies and update on the progress in new therapies and therapeutic targets based on these animal studies.

\section{DEVELOPMENTAL EQUIVALENCY BETWEEN RODENTS AND HUMANS}

Comparing development between rodents and humans is difficult due to the asynchronous maturation of different developmental milestones and processes that follow different tempos across species (reviewed in (Akman et al. 2014; Avishai-Eliner et al. 2002; Galanopoulou and Moshe 2011)). In the endocrine literature, postnatal day (PN) 0-6 rats are considered neonatal, PN7-21 infantile, whereas juvenile rats are PN21-32 in females and PN7-35 in males. Puberty onset is around PN32-35 in females and PN35-45 in males whereas adulthood begins PN60. It is customary to consider a PN8-10 rat equivalent to a term human neonate, largely due to early studies showing that the rate of brain growth, at that age is similar to that observed in humans (Dobbing 1974; Dobbing and Sands 1979; Gottlieb et al. 1977). However, this presumed equivalency may not be absolute and should be used as a possible guideline. Wild type mice follow similar milestones, although trends for earlier maturation are observed compared to rats. For example, female mice reach puberty onset around PN29 and male mice around PN26-30, although differences across studies have been reported (Kumar and Boehm 2013; Schneider 2013). The genetic background may play significant role in defining the developmental milestones, which therefore need to be confirmed for each rodent species, strain or genetically modified animal used (Clancy et al. 2001; Kumar and Boehm 2013). 
Although these accepted criteria have been helpful in the design of developmental studies, the correspondence is not absolute. While human neonates are born with eyes open, eye opening is usually between PN13-15 in rats and PN11 in mice. Humans learn to ambulate during the infantile stage. In contrast, rats learn to ambulate the first two postnatal weeks, which as a result can be considered as the infantile stage of motor development in rats (Scantlebury et al. 2010). Cautionary interpretation of the developmental equivalence is therefore recommended across different developmental processes or events.

\section{WEST SYNDROME AND INFANTILE SPASMS}

West syndrome (Pellock et al. 2010; West 1841) is an infantile epileptic encephalopathy characterized by at least two of the following features: (a) ictal events of flexion or extension spasms (IS) that usually appear in clusters, (b) interictal chaotic high amplitude and multifocally epileptic interictal background (hypsarrhythmia), and (c) intellectual or neurodevelopmental disabilities. Although IS often is used interchangeably with West syndrome, here we will use the term IS for the epileptic seizure and West syndrome for the clinical syndrome. Variations in presentation may occur, such as late-onset epileptic spasms or modified rather than classical hypsarrhythmia (Auvin et al. 2010; Dulac et al. 2010; Hrachovy et al. 1984). The treatment options are hormonal therapy (adrenocorticotropic hormone ACTH, glucocorticosteroids) or the GABA aminotransferase inhibitor vigabatrin (Go et al. 2012; Mackay et al. 2004; Pellock et al. 2010; Riikonen 2014). The ketogenic diet has shown efficacy in refractory IS (Hong et al. 2010; Pires et al. 2013). Few patients may respond to certain antiepileptic drugs (valproate, topiramate, zonisamide) or vitamin B6 (Pellock et al. 2010; Riikonen 2014).

The etiology of West syndrome is varied, with the majority $(\sim 60 \%)$ being due to structuralmetabolic etiologies while the rest are either of unknown etiology or linked to genetic defects. The unknown etiology group is the infants in which no structural-metabolic or genetic etiology can be identified with the existing diagnostic tests. With the recent advances in methods for genetic diagnosis, an increasing number of associations of IS with genetic defects has been made, which is now estimated to encompass the $12 \%$ of infants with IS (Euro Epinomics- R. E. S. Consortium et al. 2014). The list of known genetic associations with IS is presented in Supplemental Table 1. Etiology influences treatment response. A known structural-metabolic underlying etiology diminishes significantly the chance of treatment response while the unknown etiology group bears the best prognosis (Mackay et al. 2004; Pellock et al. 2010; Riikonen 2014). On the other hand, knowing the etiology may guide treatment selection, as is the case with tuberous sclerosis which is particularly responsive to vigabatrin (Curatolo et al. 2008; Nabbout 2001; Pellock et al. 2010; Riikonen 2014; Thiele 2004).

\section{Animal models}

With the workshop on animal models of pediatric epilepsies (Bethesda, 2004) where criteria were proposed for animal models of IS (Stafstrom et al. 2006), there was an increase in the interest to generate animal models that either recapitulate features of IS or test specific pathogenic hypotheses.

The excess stress / corticotropin release hormone (CRH) is one such hypothesis. Among the putative mechanisms via which ACTH may stop IS in many infants was by its effects on the hypothalamus-pituitary-adrenal (HPA) axis, whether via stimulation of adrenal steroids or via 
direct effects on the brain (Riikonen 1983). The possibility that ACTH-induced stimulation of adrenal-derived glucocorticosteroids alone is not sufficient to mediate the ACTH effects was supported by reports that ACTH was effective even in an infant with adrenal insufficiency (Willig et al. 1978). In animal studies, ACTH may reduce aggressive behavior in adrenalectomized rats (Poole and Brain 1974). Such findings drew attention to potential central effects of ACTH. In infants with IS, several studies report low ACTH levels in the CSF of infants with IS due to known or unknown etiologies compared to controls (Baram et al. 1992; Facchinetti et al. 1985; Nagamitsu et al. 2001; Nalin et al. 1985). However, the utilized controls included infants with seizures or infectious conditions. Heiskala reported higher levels of CSF ACTH in infants with IS due to unknown etiologies compared to those of known causes, although no clear normalizing effect of treatment was seen (Heiskala 1997). Comparisons with CSF levels of $\beta$-endorphin, a processing partner of ACTH from the common precursor proopiomelanocortin (POMC) provided inconclusive data and no definite evidence for POMC production and processing deficit (Heiskala 1997; Nagamitsu et al. 2001; Nalin et al. 1985). Furthermore, no definite differences in CSF corticotropin release hormone (CRH) levels have been reported in IS compared with controls, although this may not exclude local differences in CRH expression and signaling in selected brain nuclei (Baram et al. 1992; Nagamitsu et al. 2001).

In the early 1990s, Baram proposed the corticotropin release hormone (CRH) excess theory of IS (Baram 1993), whereby abnormal, excessive CRH production, release or response in the context of early life stress may lead to seizures like IS. The first week of life in rats seemed, as a result, the most vulnerable given that expression studies of CRH receptors and $\mathrm{CRH}$ indicate a high amount of unoccupied CRH receptors (Baram and Lerner 1991; Insel et al. 1988). Intracerebral CRH injections given to PN5 rats intracerebroventricularly (i.c.v.) indeed confirmed the proconvulsant properties of CRH in PN14 or younger rats but not in PN18 (Baram and Schultz 1991). However, CRH induced seizures were not spasms but rather limbic, originating in the amygdala, and were responsive to phenytoin but not ACTH (Baram and Schultz 1991). Attempts to test the effects of $\alpha$-helical $\mathrm{CRH}$, a competitive inhibitor, in human infants with IS failed to demonstrate any therapeutic effect, although there was no evidence for brain penetration (Baram et al. 1999). Overall, the CRH excess theory introduced an interesting hypothesis linking early life stressors to early life seizures, however the relevance to IS is at present unclear.

Of interest, a clinical study probed the levels of prenatal stress in the mothers of infants with IS or positive controls (infants with other types of epilepsies) or negative controls (no epilepsy controls) (Shi et al. 2012). Using a questionnaire that graded the levels of different types of stressors, both positive and negative life events, the investigators found significantly higher levels of prenatal stress in the mothers of infants with IS compared to either positive or negative controls. It would be interesting to follow up with prospective, large study cohorts to further test this association, also as a function of etiology, although this could be difficult to achieve, given the low incidence of IS.

Table 1 shows the currently published models of IS. These models can be distinguished into (a) acute, i.e. those that manifest epileptic spasms only during the few post-induction hours, and (b) chronic, i.e. those that exhibit a chronic phenotype with similarities to West syndrome. As will be reviewed below, these models have since offered valuable information on mechanisms 
involved in the expression of IS or West syndrome as well as indicated a number of new candidate treatments.

\section{Acute models}

a. The N-methyl-D-aspartate (NMDA) based models. In addition to the NMDA model, in which systemic injections of the glutamatergic drug NMDA are known to induce seizures acutely, there are several variations that also include prior interventions that cause perinatal stress.

(i) NMDA-alone model.

Intraperitoneal (i.p.) injections of NMDA given to immature rats induce a particular seizure type, named emprosthotonic seizures (Mares and Velisek 1992). Emprosthotonic seizures occurred during the first post-NMDA injection hour, manifested in PN18 or younger rats only, and semiologically resembled flexion tonic spasms. Additional NMDA-induced behaviors and seizures manifest in a dose and age dependent manner, including hyperactivity, tail twisting, clonic and tonic seizures (Kabova et al. 1999; Mares and Velisek 1992), a state which has also been described as NMDA-induced status epilepticus (SE) (Stafstrom and Sasaki-Adams 2003). The EEG showed low voltage background and no clear correlates to emprosthotonic seizures in (Mares and Velisek 1992) and reversible EEG suppression during emprosthotonus and "serrated waves" (slow waves with superimposed fast activity) during behavioral arrests in (Kabova et al. 1999). Extensive testing has been done in this model to determine if drugs that show efficacy of spasms prevent or delay the expression of tonic spasms when given prior to seizure induction (Table 2). Initial studies utilizing $\mathrm{ACTH}_{1-24}$ or rat $\mathrm{ACTH}_{1-39}$ pretreatment showed no effect on emprosthotonic seizures (Velisek et al. 2007). Pretreatment with high dose porcine $\mathrm{ACTH}_{1-39}$, however, reduced spasms in an independent study (Wang et al. 2012c). Pretreatment with high doses of vigabatrin also reduced spasms (Kubova and Mares 2010) whereas variable results were seen with other drugs (Table 2) (Kabova et al. 1999; Kubova and Mares 2010; Velisek and Mares 1995).

In the long-term studies, deficits in learning and coordination and reduced latencies for class $\mathrm{V}$ pentylenetetrazole induced generalized tonic clonic seizures have been reported but no overt epilepsy (Stafstrom and Sasaki-Adams 2003). The value of this NMDA model is that it has suggested a possible role for NMDA receptors in the acute expression of tonic spasms. However no chronic epilepsy ensues. It is interesting that recent genetic associations have linked mutations of NMDA receptors 1 (GRIN1) and 2B (GRIN2B) to patients with epileptic encephalopathies and IS (Epi4K. Consortium et al. 2013; Lemke et al. 2014). Two of the GRIN2B mutations were gain of function mutations, because they were not sensitive to $\mathrm{Mg}^{++}$blockade and exhibited increased $\mathrm{Ca}^{++}$permeability (Lemke et al. 2014).

\section{(ii) The perinatal stress - NMDA models.}

The stress theory of IS pathogenesis has led to several variations of the NMDA model which introduced perinatal interventions that can alter HPA and stress responses prior to the postnatal administration of NMDA. Prenatal i.p. administration of betamethasone or forced restraint stress in pregnant rats at gestational day $15(\mathrm{G} 15)$ accelerated the onset and increased the number of acute emprosthotonic seizures after NMDA injection in PN15 offspring (Chachua et al. 2011; Velisek et al. 2007; Yum et al. 2012). Forcing the pregnant dams to swim in cold water also 
accelerated and increased NMDA-induced spasm frequencies in PN13 rats (Wang et al. 2012b). Postnatal adrenalectomy in PN10 Wistar rats also reduced the latency to and severity of NMDAinduced spasms on PN11 (Wang et al. 2012c). These models supported the idea that perinatal stress may deteriorate the course of untreated NMDA spasms (shortens the latency and increases the number of NMDA acute spasms), yet the fact that all NMDA-injected rats manifest spasms deterred from showing any effect on incidence of spasms, as suggested by the clinical study on prenatal stressors (Shi et al. 2012).

A positive aspect of prenatal stressors is that they may improve the responsiveness of NMDA spasms to ACTH. Doses of $\mathrm{ACTH}_{1-39}$ pretreatment, that had no effect on the NMDA model, effectively delayed the onset of acute NMDA spasms on PN15 rats that had been primed with betamethasone on G15 (Velisek et al. 2007) or exposed to prenatal forced swim stress (Wang et al. 2012b). Prenatally restrained rats, however, failed to respond to a single dose of $\mathrm{ACTH}_{1-39}$ pretreatment but required repetitive administration of higher $\mathrm{ACTH}_{1-39}$ doses (9 total doses of $0.3 \mathrm{mg} / \mathrm{kg}$, between PN12-14) subcutaneously (s.c.) to delay and diminish NMDA spasms on PN15 (Yum et al. 2012). These doses however also impaired weight gain (Yum et al. 2012).

Among the other drugs tested in these models (Table 2), vigabatrin and methylprednisolone (repetitive but not the single dose) have shown efficacy when given prior to NMDA induction (Chachua et al. 2011). The mTOR inhibitor rapamycin, previously shown to be effective in the multiple-hit model of IS given after the onset of spasms (Raffo et al. 2011), had no effect when given prior to NMDA induction (Chachua et al. 2011). However, the relevance of these findings is unclear, due to the lack of any evidence for mTOR relevance or engagement in the betamethasone / NMDA model and the different age groups used in the two studies that make the dose equivalence unclear. Most importantly, the effects of rapamycin on naïve rats (as done in the NMDA model) are different compared to those in subjects with epilepsy (as in the multiplehit model) (Raffo et al. 2011). More recently, pretreatment with ganaxolone, a neuroactive steroid, delayed and reduced NMDA spasms in the prenatal betamethasone model (Yum et al. 2014). The therapeutic relevance of ganaxolone in IS is currently unclear because the effect on spasms or flurothyl seizures was only observed with high doses that can produce motor impairment (Liptakova et al. 2000; Yum et al. 2014). In a multicenter open label, add-on clinical trial of ganaxolone in infants with refractory IS, 33\% of the infants responded with at least 50\% reduction in spasms but only one of the 15 patients became spasm-free (Kerrigan et al. 2000). The overall efficacy of ganaxolone in this study, measured as spasm cessation, is less than with other therapies (i.e. ACTH, vigabatrin) where optimal outcome is considered the spasm cessation, yet the ganaxolone study included only refractory, and not new-onset, IS. There are no other published studies known to the authors that have evaluated ganaxolone for human IS.

These prenatally stressed models have provided useful tools to study mechanisms and brain regions implicated in the ACTH responsiveness of NMDA spasms, with particular emphasis on the hypothalamic structures and peptides. Proteomics analysis of total brain content in the prenatal forced swim / postnatal NMDA model identified few proteins the expression of which changed as a result of ACTH pretreatment (Wang et al. 2012b). These were implicated in functions and pathways potentially affecting neuronal development. However, similar to the NMDA model, none of these models is known to manifest spontaneous seizures. As a result, readministration of NMDA has been used to study the effects of various treatments on repetitive 
NMDA-induced spasms over several days (Chachua et al. 2011). The NMDA and prenatally stressed NMDA models have been proposed as models of IS of unknown etiology and it is unclear how relevant these target mechanisms may be for the ACTH-refractory IS.

\section{b. The $\gamma$-butyrolactone /Ts65Dn mouse model.}

The incidence of IS in Down syndrome ranges between 1.5-32\% (Goldberg-Stern et al. 2001; Pueschel et al. 1991; Romano et al. 1990; Sanmaneechai et al. 2013). The presence of increased $\mathrm{GABA}_{\mathrm{B}}$ receptor $\left(\mathrm{GABA}_{\mathrm{B}} \mathrm{R}\right)$ mediated potassium currents in a mouse model of Down syndrome, Ts65Dn (Best et al. 2007), was a reason to test the effects of $\gamma$-butyrolactone, a prodrug of the $\mathrm{GABA}_{\mathrm{B}} \mathrm{R}$ agonist $\gamma$-hydroxybutyrate (Cortez et al. 2009). Although $\mathrm{GABA}_{\mathrm{B}} \mathrm{R}$ agonists trigger absence type seizures in other strains, in Ts65Dn mice, $\gamma$-butyrolactone i.p. injection triggered facial myoclonus, vibrissae twitching and acute epileptic extensor spasms associated with electrodecremental responses (EDR) (Cortez et al. 2009). However, spasms are only acutely present and no other epilepsy phenotype has been reported as a result of $\gamma$-butyrolactone injections. Similar to human IS, spasms in this model respond to ACTH (rat $\mathrm{ACTH}_{1-24}$, but not porcine $\mathrm{ACTH}_{1-39}$ ) and vigabatrin. Drugs that reduce EDRs include valproate and $\mathrm{GABA}_{\mathrm{B}} \mathrm{R}$ antagonists, consistent with the $\mathrm{GABA}_{\mathrm{B}} \mathrm{R}$ mediated induction mode. 5-hydroxytryptophan worsened EDR, consistent with a clinical observation that this drug increased IS in a cohort of patients with Down syndrome (Coleman 1971). Unexpectedly, ethosuximide also reduced EDRs, although no such evidence exists in human IS. This model has underlined the importance of $\mathrm{GABA}_{\mathrm{B}} \mathrm{R}$ pathway in the pathogenesis of spasms in Down syndrome.

\section{Chronic models:}

\section{a. The tetrodotoxin (TTX) rat model.}

Frost and Hrachovy had proposed that the asynchronous maturation of brain regions ("developmental desynchronization") due to various genetic or acquired etiologies may underlie the pathogenesis of IS (Frost and Hrachovy 2005). The TTX model attempted to model a focal arrest of brain development by focal chronic infusion of TTX, a sodium channel blocker, in the right cerebral cortex or hippocampus of Wistar rats starting at PN10-12 and continuing for 4 weeks (Lee et al. 2008). In the TTX model, spasms with EDRs start to appear around PN21 and continue till adulthood without remission. Although the persistence of TTX spasms does not conform to the typical age-specificity of the classical IS, it has allowed to monitor ictal and interictal EEG patterns with multiple electrodes in older animals, something that is not currently possible in the younger rats. Interictal EEGs in older animals identified an abnormal interictal high amplitude, chaotic epileptic background, particularly during non REM (NREM) sleep that resembled hypsarrhythmia or hemihypsarrhythmia in certain cases where lower voltage was present over the right frontocentral regions that were close to the TTX infused region (Lee et al. 2008). Further, high frequency oscillations have been reported both ictally and interictally in this model but were more prominent contralateral to the infusion hemisphere (Frost et al. 2011; Frost et al. 2012). There are no published data yet on the effects of ACTH or vigabatrin in this model.

\section{b. The Aristaless-related homeobox X-linked (Arx) mouse models.}

Arx is a transcriptional factor involved in the migration of GABAergic progenitors and early commitment of cholinergic neurons (Friocourt and Parnavelas 2010). Arx genetic defects have been found in various early life epileptic encephalopathies, including West syndrome, and may or may not show pronounced structural brain and other abnormalities, as in X-linked 
lissencephaly with abnormal genitalia (XLAG) (Dobyns et al. 1999; Kato et al. 2003; Stromme et al. 2002). Neuropathological features of XLAG include loss of cortical interneurons, gliosis and heterotopic neurons in the periventricular white matter, corpus callosum agenesis, disorganization and atrophy of the striatum and diencephalon (Bonneau et al. 2002). The migration deficit or decrease in cortical interneurons has been documented in 6 of the existing 8 mouse models of ARX (Kitamura et al. 2009; Marsh et al. 2009; Price et al. 2009), introducing the term "interneuronopathy" as a characteristic pathology underlying ARX-related syndromes (Kato and Dobyns 2005). Mice with conditional Arx deletion at the dorsal telencephalon (Arx ${ }^{-}$ $\left.{ }^{/ Y} \mathrm{Emx} 1^{\mathrm{Cre}}\right)$ do not demonstrate interneuronopathy, consistent with the Emx1 specification for cortical pyramidal neurons (Chan et al. 2001; Simonet et al. 2014). In contrast, conflicting reports of presence or absence of interneuronopathy have been published for the Arx ${ }^{(\mathrm{GCG}) 7 / \mathrm{Y}}$ mice (Beguin et al. 2013; Kitamura et al. 2009).

Only two ARX mouse strains have reported epileptic spasms: the knockin (KI) model with extension of the first polyalanine repeats of Arx (Arx ${ }^{(\mathrm{GCG}) 10+7}$ ) (Price et al. 2009) and a conditional knockout model (ARX cKO) with Arx deletion from the ganglionic eminence (Marsh et al. 2009) (Table 1). The Arx ${ }^{(\mathrm{GCG}) 10+7} \mathrm{KI}$ mouse model manifests epileptic spasms between PN7-20 followed by other types of seizures (behavioral arrests, generalized tonic-clonic seizures, limbic seizures), as well as learning and sociability deficits (Price et al. 2009). The ARX cKO mouse manifests limbic seizures around PN14-17 and epileptic spasms in adulthood (Marsh et al. 2009). Seizures but not spasms have been described in the Arx ${ }^{(\mathrm{GCG}) 7 / Y}$ male mice with polyalanine expansion and the Arx ${ }^{\mathrm{P} 355 \mathrm{~L}}$ knockin mice (Kitamura et al. 2009). The Arx ${ }^{-}$ ${ }^{/ Y} \mathrm{Emx} 1{ }^{\mathrm{Cre}}$ mice without interneuronopathy do not have seizures (Simonet et al. 2014). Overall, all the Arx mouse strains that manifest spasms and / or seizures also have interneuronopathy, supporting its possible association with these epilepsies. Many of the above strains also have behavioral deficits, including the $\mathrm{Arx}^{-/ \mathrm{Y}} \mathrm{Emx} 1^{\mathrm{Cre}}$, underlining that etiology is an important factor in determining IS-related comorbidities (Price et al. 2009; Simonet et al. 2014).

The effects of ACTH or vigabatrin in the Arx mice have not yet been tested. An interesting disease modifying effect of neonatal estradiol, given prior to the first observation of spasms, was reported in the $\operatorname{Arx}^{(\mathrm{GCG}) 10+7}$ mice (Olivetti and Noebels 2012). Early (PN3-10) but not late (PN33-40) administration of estradiol restores the underlying interneuronopathy and ameliorates epilepsy in this model, indicating the existence of a sensitive period for the effects of estradiol. The fact that this is a genetic etiology IS model allows the consideration and implementation of treatments starting prior to the onset of spasms. However, more studies are needed to determine what is the specific developmental period in humans and if this treatment might be relevant for IS of different etiologies.

\section{c. The multiple-hit rat model of IS due to structural lesion.}

The multiple-hit model of IS was designed to model the more refractory form of IS due to structural lesions. Neuropathological and imaging studies had implicated cortical and subcortical pathologies in infants with IS which led to the hypothesis that aberrant cortical-subcortical communication patterns may underlie IS (Lado and Moshe 2002). The induction method utilized in this model included therefore right intracerebroventricular infusions of the cytotoxic agent doxorubicin and right intracortical infusion of the lipopolysaccharide to target white matter, both given on PN3 (Scantlebury et al. 2010). A subsequent intraperitoneal injection of the tryptophan 
hydroxylase inhibitor p-chlorophenylalanine (PCPA) was given on PN5 to deplete serotonin, due to old reports that serotonin metabolism may be abnormal in infants with IS (Langlais et al. 1991; Silverstein and Johnston 1984; Yamamoto 1991). This protocol resulted in the expression of spasms between PN4-13 indicating that PCPA was not necessary for their expression. PCPA has been retained in the induction protocol because it increases the frequency of spasms. Spasms are associated with epileptic ictal patterns and EDRs with fast oscillatory activity while interictally the background is epileptic (Briggs et al. 2014; Ono et al. 2011; Raffo et al. 2011; Scantlebury et al. 2010).

The multiple-hit protocol results in cortical and subcortical lesion predominantly in the right hemisphere, including the right sensorimotor cortex and hippocampus (Briggs et al. 2014; Jequier Gygax et al. 2014). On PN5 it mainly involves the right anterior dorsal hippocampus but on PN20 it may expand to the right posterior and ventral hippocampus. Specific stains however indicate loss of interneurons at the contralateral homotypic sensorimotor cortex, with the remaining showing abnormal morphology (unpublished data).

This model generates a chronic evolving phenotype including spasms (PN4-13), other types of seizures starting on PN9 (behavioral arrest, wild running, myoclonic, myoclonic-drop attacks, or seizures resembling stage 4-5 limbic seizures), and adult epilepsy (Akman et al. 2012; Raffo et al. 2011; Scantlebury et al. 2010). Spasms occur only between PN4-13, when pups learn to ambulate, as infants do. Furthermore, deficits in learning and sociability and transient deterioration of neurodevelopmental motor reflexes during the period of spasms have been documented (Raffo et al. 2011; Scantlebury et al. 2010).

The multiple-hit model has been extensively used for screening for new therapies given after the onset of spasms, as in clinical practice. Similar to the IS from structural lesions, the observed spasms are more refractory to current therapies: ACTH has no effect while vigabatrin transiently reduces spasms (Scantlebury et al. 2010). Treatments that are not effective in human IS, like phenytoin, have no effect in this model (Ono et al. 2011).

There is a high association of human IS with conditions showing mTOR overactivation (reviewed in (Galanopoulou 2013; Galanopoulou et al. 2012)). 38\% of people with tuberous sclerosis have IS, while few of the known etiologies for IS (hemimegalencephaly, focal cortical dysplasias type IIB (FCDIIB), genetic defects) demonstrate increased activity of the mTOR pathway or its downstream targets (Chu-Shore et al. 2010; Epi4K. Consortium et al. 2013; Euro Epinomics- R. E. S. Consortium et al. 2014; Orlova and Crino 2010; Orlova et al. 2010). Increased expression of the phosphorylated form of ribosomal protein S6 (pS6) was also seen in the cortex of the multiple hit model rats during the period of spasms (Raffo et al. 2011). Administration of pulse high dose of rapamycin, an mTOR inhibitor, given after the onset of spasms on PN4-6, successfully stopped spasms and partially improved learning. This demonstrates that cognitive deficits are not just due to the structural lesion and may be modifiable in an mTOR-dependent manner (Raffo et al. 2011) (Table 3).

A single i.p. dose of carisbamate acutely suppressed spasms during the first 3 hours, through an unknown mechanism independent of sodium channel blockade (Ono et al. 2011). Carisbamate has since been granted orphan drug status for IS by the Food and Drug Administration (FDA). 
Another promising drug is CPP-115, a vigabatrin analog with high affinity for GABA aminotransferase that has shown lower retinal toxicity than vigabatrin (Pan et al. 2012; Silverman 2012). CPP-115 reduced spasms in the multiple-hit model showing better efficacy / tolerability profile than vigabatrin, at doses 400 times lower than vigabatrin (Briggs et al. 2014). CPP-115 did not affect cognitive or neurodevelopmental deficits, consistent with the clinical literature on vigabatrin (Lux et al. 2005). However, if the lower risk for retinal toxicity is also confirmed in clinical trials, it may offer a safer therapeutic option for the infants who are candidate for vigabatrin. CPP-115 has been designated orphan drug for IS by FDA and is currently on phase I trials. We found no effect for a galanin receptor 1 (GalR1) analog NAX 5055 , although the low developmental expression of GalR1 could be the reason for the lack of effect (Jequier Gygax et al. 2014).

\section{Insights from the animal models for IS pathogenesis.}

The animal models have supported the relevance to IS of few of the genetic pathways suggested by the human genetic associations (Supplemental Table 1), including NMDA receptors, GABA $A_{B}$ receptors in Down syndrome, ARX, mTOR pathway, cortical-subcortical lesions in early life. However, only certain of these induction methods result in chronic phenotype.

The chronic phenotype of the syndrome ensues only in either genetic models (i.e. ARX) or models associated with underlying lesions (multiple-hit model) or after chronic infusion of chemical inducers (TTX model), suggesting that long-term presence of the inducer and/or associated pathology is needed to functionally reset the networks so that the epilepsy and cognitive phenotype of West syndrome emerges. Specific pathologies documented in situ in some of these models include interneuronopathy from genetic or acquired causes (ARX, multiple-hit model) and mTOR overactivation (multiple-hit model). Therapies, like mTOR inhibitors, that ameliorate these pathologies have also improved partially the cognitive abnormalities, emphasizing the value of targeting the relevant pathologies to effect disease modification.

Little is currently known on the pathophysiology of hypsarrhythmia, since extensive video-EEG studies with sufficient number and spread of electrodes is not possible currently in the very young animals. The TTX model of hypsarrhythmia has provided electrophysiologic evidence for multifocal abnormalities and pathologic high frequency oscillations (HFOs) but correlation with specific histopathological substrates has not been done yet.

Are IS and non-IS epileptogenesis due to the same pathological cascades? All the chronic models of IS exhibit long-term epilepsy with seizures other than IS, yet not all animals with epileptic spasms manifest other seizures implying the presence of protective factors. It is currently unclear if early epileptic spasms are necessary for the development of other types of seizures in these models. In the multiple-hit model in which all rats develop spasms, early cessation of spasms with pulse rapamycin did not affect the early appearance of other seizure types till PN20. In human studies, it is however also known that IS cessation does not prevent the expression of other types of seizures. Long-term studies testing the potential anti-epileptogenic effect of pulse rapamycin on the adult epilepsy are currently ongoing in the multiple-hit model. However, the relative persistence of early seizures, despite the cessation of spasms by pulse rapamycin, shows 
the complexity of epileptogenic processes involved in different types of seizures and possibly the need to explore epileptogenesis as a function of seizure type. The availability of an increasing number of diverse models promises to help unravel the pathophysiology and treatment options for IS and associated epilepsies and comorbidities. The challenge lies in that each of these models is on a different species or age during development, which guarantees ongoing changes in brain biology, connectivity and function (Galanopoulou and Moshe 2011). Further characterization of these models and drug doses for target relevance and engagement by the tested therapeutics will be necessary to fully evaluate the potential and indication of each tested treatment.

\section{DRAVET SYNDROME, GENETIC EPILEPSIES WITH FEBRILE SEIZURES PLUS (GEFS+)}

Dravet syndrome or severe myoclonic epilepsy of infancy usually appears with prolonged febrile seizures, clonic or hemiclonic, and progresses with afebrile seizures that include myoclonic seizures, atypical absences, focal or generalized seizures (Dravet and Oguni 2013). Seizures do not usually respond to the available antiepileptic drugs and patients may exhibit paradoxical seizure exacerbation by phenytoin or lamotrigine. Dravet syndrome also exhibits high risk for sudden death in epilepsy (SUDEP). Dravet syndrome has been linked to genetic defects in sodium channels (SCNs), like SCN1A (70-80\% of patients) or SCN1B, rarely the $\gamma 2$ subunit of $\mathrm{GABA}_{\mathrm{A}}$ receptors $(\mathrm{GABRG} 2$ ), while a Dravet syndrome-like phenotype was linked with protocadherin PCDH19 mutations (Claes et al. 2001; Fujiwara et al. 2003; Marini et al. 2011; Nabbout et al. 2003; Ohmori et al. 2002; Patino et al. 2009; Sugawara et al. 2002). SCN1A mutations have also been described in more benign syndromes, like the genetic epilepsies with febrile seizures plus syndrome (GEFS+), which may include individuals with febrile or afebrile seizures (focal or generalized) in the same families (Escayg and Goldin 2010; Escayg et al. 2000). The more severe phenotype of Dravet syndrome due to SCN1A defects has been attributed to loss of function SCN1A defects in Dravet syndrome as opposed to altered channel activity (occasionally gain of function) in GEFS+ (Escayg and Goldin 2010; Schutte et al. 2014).

\section{Animal models:}

Several animal models of SCN1A or SCN1B defects have been generated in rodents or nonmammalian species (Table 4). Most exhibit either spontaneous or thermally induced seizures. The animal models of Dravet and GEFS+ syndromes have demonstrated differences in the pathogenic consequences of SCN1A or SCN1B defects. Functional interneuronopathy has been implicated in Dravet syndrome due to SCN1A genetic defects whereas overactivity of excitatory neurons in SCN1B related Dravet syndrome. The availability of both rodent and non-mammalian models has already started to yield promising results in identifying candidate therapies.

In favor of the theory that interneurons are dysfunctional in the SCN1A mice, enhancement of $\mathrm{GABA}_{\mathrm{A}}$ receptor transmission had beneficial effects in several mouse models. Clonazepam, a $\mathrm{GABA}_{\mathrm{A}}$ receptor allosteric modulator, protected against myoclonic and generalized tonic-clonic thermally induced seizures in the SCN1A KO mouse (Oakley et al. 2013) and also improved abnormal social behaviors and deficits in fear memory (Han et al. 2012). Tiagabine, a presynaptic GABA uptake inhibitor, protected against generalized tonic-clonic seizures but had dose-dependent effects against myoclonic seizures (Oakley et al. 2013). In the R1407X SCN1A $\mathrm{KI}$ mouse, a drug that enhances $\mathrm{GABA}_{\mathrm{A}}$ receptor function and possibly GABA levels, 
stiripentol, increased the threshold to thermal seizures and had synergistic effect with clonazepam (Cao et al. 2012). In the N1417H SCN1A rat, methylphenidate inhibited thermally induced seizures and improved hyperactivity and spatial learning (Ohmori et al. 2014). Ketogenic diet improved flurothyl seizure thresholds in the heterozygous SCN1A KO and R1648H mice (Dutton et al. 2011). Genetic ablation of tau protein in the R1407X KI mouse reduced mortality and epilepsy severity, suggesting that targeting this pathway might be of benefit (Gheyara et al. 2014).

The zebrafish model has allowed for higher throughput screening of new therapies, based on the type and frequency of swim and the effects on electrophysiologically recorded activities in agarimmobilized larvae (Baraban et al. 2013). In the zebrafish Scn1Lab model, effective antiseizure treatments included ketogenic diet, diazepam, valproate, potassium bromide and stiripentol, whereas vigabatrin, carbamazepine, ethosuximide, phenytoin, had no effect. In this screen, a new compound, the H1 antagonist and NS4B RNA-inhibitor clemizole also showed efficacy posing this as a candidate new drug for further preclinical evaluation.

Increased mortality is noted in some of these models, like the R1407X KI model (Auerbach et al. 2013; Ogiwara et al. 2007), the SCN1A cKO model in forebrain or hippocampal neurons (Cheah et al. 2012) or GABAergic interneurons (Ogiwara et al. 2013), the R1648H KI mouse (Martin et al. 2010) and the SCN1B KO (Chen et al. 2004) or SCN1B C121W KI (Reid et al. 2014) mouse models. Using conditional SCN1A knockouts, Ogiwara et al demonstrated that selective deletion in GABAergic interneurons triggers epilepsy and early mortality while deletion in forebrain excitatory neurons does not (Ogiwara et al. 2013). Another interesting feature is the compensatory role of the network in these interactions, since dual knockout of SCN1A in both excitatory and inhibitory neurons may ameliorate epilepsy (Ogiwara et al. 2013). Furthermore, the strain used may modify the severity of the phenotype. Heterozygous SCN1A+/- mice on 129S6/SvEvTac had no overt phenotype, unlike C57BL/6J that had severe epilepsy and early mortality (Mistry et al. 2014). These strain differences also followed the gene-related abnormalities in sodium currents.

Both central and cardiac causes have been evoked to explain the early lethality. Mortality was higher in brain than in cardiac specific SCN1A knockouts, supporting a seizure or CNS related etiology in early death (Kalume et al. 2013). However, cardiac arrhythmias were noted in the R1407X SCN1A KI mouse and cardiac myocyte hyperexcitability (Auerbach et al. 2013) supporting that cardiac abnormalities may also contribute and potentially aggravate the cardiac function under seizure-related stress.

\section{OTHER GENETIC EIEES}

Several genes have been linked so far with EIEEs presenting early in life with different types of seizures including tonic spasms, myoclonic or focal seizures (Carvill et al. 2013). For some of these conditions genetic mouse models have been generated to test the epileptogenic effects of the mutation and mechanisms underlying these. These include the ARX models (EIEE1) and SCN models (Dravet syndrome, GEFS+, EIEE6) described above. Here we will refer to selected EIEEs for which there are mouse models generated for the relevant genetic defects. Interestingly, 
most of these mouse models of EIEE have been used to study possible mechanisms but have not consistently yielded epilepsy phenotypes.

\section{EIEE2 and CDKL5}

Cyclin dependent kinase like 5 (CDKL5) mutations may lead to early onset seizures and hypotonia, epileptic encephalopathy with IS, and refractory tonic or myoclonic seizures and atypical Rett semiology. Subsequent features include stereotypies, motor rigidity and language or cognitive deficits. CDKL5 is a Ser/Thr kinase that maps on $\mathrm{X}$ chromosome and therefore predominantly affects girls (Kalscheuer et al. 2003; Scala et al. 2005; Weaving et al. 2004). The mutations are thought to result in loss of function of CDKL5 a kinase that in vitro phosphorylates $\mathrm{MeCP} 2$, providing a link to the genetic pathway that is disturbed in Rett syndrome (Mari et al. 2005).

Deletion of CDKL5 in mice reproduced several of the neurological phenotypes but there was no epilepsy detected in hemizygous male mice. Loss of CDKL5 in male mice generates autistic-like phenotype and deficits in motor control and fear memory (Wang et al. 2012a). In a subsequent study CDKL5 KO mice showed hypoactivity, limb clasping, abnormal eye tracking and reduced amplitude of visual evoked potentials with a gene dosage effect on motoric deficits (Amendola et al. 2014). The phenotype in conditional CDKL5 KO mice was different in deletions targeted to the Emx1-positive excitatory (hindlimb clasping) versus Dlx5/6-positive inhibitory neurons (hypoactivity) in male hemizygous mice (Amendola et al. 2014). Pathologically there was reduced activity of the mTOR pathway (Amendola et al. 2014; Wang et al. 2012a).

\section{EIEE4 and STXBP1}

Syntaxin binding protein 1 (STXBP1, MUNC18-1) is involved in presynaptic neurotransmitter release. STXBP1 gene defects have been identified in early epileptic encephalopathies in humans, such as early onset IS, EIEE with suppression bursts, focal or multifocal seizures (Barcia et al. 2013; Barcia et al. 2014; Boutry-Kryza et al. 2015; Epi4K. Consortium et al. 2013; Michaud et al. 2014; Saitsu et al. 2010). Many of these reports describe refractory seizures (tonic, myoclonic, clonic), intellectual disabilities. However, in some cases the course is benign ending in seizure freedom or control and is associated with characteristic MRI patterns of frontal hypoplasia, thin and dysmorphic corpus callosum (Barcia et al. 2014). In mice, haploinsufficiency of STXBP1 results in anxiety-like behavior but no seizures have been reported (Hager et al. 2014). Munc18-1 deficient mice have been used for their inability to secrete neurotransmitters and showed that Munc18-1 KO does not impair synaptogenesis but is important in maintenance of synapses.

\section{EIEE7 and KCNQ2}

KCNQ2 are voltage sensitive $\mathrm{K}^{+}$channels that are important for the maintenance of resting membrane potential and repolarization of neurons during the termination of the action potentials. KCNQ2 channel mutations have been linked with benign familial neonatal convulsions or "fifth day fits" which have benign prognosis. Occasional cases of more severe epilepsy course have been reported with IS or suppression bursts and cognitive impairment (Epi4K. Consortium et al. 2013; Euro Epinomics- R. E. S. Consortium et al. 2014). KCNQ2 KO mice have confirmed the gene importance for excitability even though no spontaneous seizures have been reported in these mice. KCNQ2 heterozygous mice have increased sensitivity to pentylenetetrazole (PTZ) 
seizures (Watanabe et al. 2000). Similarly, Szt1 mice that have low threshold to electroconvulsive seizures have a $300 \mathrm{~kb}$ deletion that includes the last four exons of KCNQ2 gene (Yang et al. 2003)

\section{EIEE13 and SCN8A}

Sodium channel 8A or Nav1.6 $\alpha$ subunit is highly expressed in the brain and especially at the axon initial segment and nodes of Ranvier where they control the initiation and propagation of action potentials. At least 30 de novo mutations in SCN8A have been described in individuals with early infantile epileptic encephalopathy 13 (EIEE13) who had early refractory epilepsy, autism and intellectual disabilities and occasionally with movement disorders or SUDEP (Blanchard et al. 2015; Epi4K. Consortium et al. 2013). SCN8A mutations have also been described among the de novo mutations found in IS and Lennox Gastaut syndrome (Epi4K. Consortium et al. 2013). Three of the seven SCN8A mutations identified so far were gain of function (N1768D, T767I, N984K) (Blanchard et al. 2015; Estacion et al. 2014; Veeramah et al. 2012).

Wagnon et al recently described the phenotype of a SCN8A N1768D KI mouse that manifested tremor and ataxia followed by generalized clonic-tonic seizures and death. The age at expression of these symptoms was younger in the homozygous (D/D) than in the mouse with a single allele that harbored the mutation, while no symptoms were evident in mice with one mutated and one wild type allele (D/+) (Wagnon et al. 2015). The authors explain the delayed onset of the symptoms by the compensatory presence of SCN2A at the axon initiating segment during the first two weeks of life. Other models of loss of function of SCN8A may demonstrate movement disorders and cerebellar symptoms, such as dystonia, ataxia, tremor and progressive paralysis (Kearney et al. 2002; Sprunger et al. 1999).

\section{EIEE15 and ST3GAL3}

ST3 beta-galactoside alpha-2,3-sialyltransferase 3 (ST3GAL3) mutations have been described in West syndrome patients (Edvardson et al. 2013). ST3GAL3 catalyzes the transfer of sialic acid onto galactose containing substrates. ST3GAL3 is one of the two sialyltransferases responsible for the terminal sialylation of brain gangliosides (Sturgill et al. 2012). Dual ST3GAL3 / ST3GAL2 KO mice lack almost all of the gangliosides in the brain and have problems thriving, are small in weight and die prematurely (Sturgill et al. 2012). ST3GAL3 deficient mice show enhanced allergic eosinophilic airway inflammation (Kiwamoto et al. 2014), small litter size (Sturgill et al. 2012) but the neurological phenotype was not described. The exact mechanisms involved in epileptogenesis in this genetic condition are not known. It is possible that deficiency of this enzyme could disturb the membrane localization and functionality of receptors and other plasma membrane molecules involved in signaling pathways. Additionally, it may enhance inflammatory or autoimmune processes that could contribute to epileptogenesis.

\section{EIEE17 and GNAO1}

De novo mutations of GNAO1, $\alpha$ subunit of $G_{o}\left(G \alpha_{0}\right)$ which is a $G_{i / o}$ protein that inhibits adenylyl cyclase, were found in four girls with EIEE, three of which had Ohtahara syndrome. The fourth manifested opisthotonus and developmental delay at 7 months. Two of the patients with Ohtahara syndrome progressed to hypsarrhythmia and two had involuntary movements (dystonia or chorea and athetosis) (Nakamura et al. 2013). Myelination defects were present in 
two of the patients. The predicted consequences of the human mutations are either destabilization of the Ga fold or impairment of GTP binding or downstream signaling (Nakamura et al. 2013).

Mice heterozygous for the G184S Gnao1 gain of function mutation manifest early lethality, epileptic discharges in the EEG and increased sensitivity to PTZ kindling and rare spontaneous seizures (Kehrl et al. 2014). Interestingly strain seemed as an important modifier of the phenotype: early lethality and susceptibility to PTZ kindling was seen on a B6 but not on a 129 background.

\section{EIEE18 and SZT2}

Seizure threshold 2 homolog (Szt2) gene was first associated to low threshold for electroconvulsive (ECT) seizures and increased kindling susceptivility in mice that had undergone ethylnitrosurea (ENU) mutagenesis (Frankel et al. 2009). Szt2 is a peroxisomal protein involved in oxidative stress response. While no spontaneous seizures have been described in this mouse, several reports linking Szt2 genetic defects to either epilepsy and/or intellectual disabilities have surfaced (Basel-Vanagaite et al. 2013; Falcone et al. 2013). Complete loss of Szt 2 leads to early onset autosomal recessive epileptic encephalopathies, severe neurodevelopmental deficits and dysgenesis of corpus callosum (Basel-Vanagaite et al. 2013). Mutations predicted to have a lesser impact in Szt2 function caused milder intellectual disabilities not necessarily associated with epilepsy (Falcone et al. 2013).

\section{$\underline{\mathrm{MEF} 2 \mathrm{C} \text { disruption }}$}

Myocyte enhancer factor-2 family member $\mathrm{C}(\mathrm{MEF} 2 \mathrm{C})$ has been implicated in myogenesis, cardiac, neural crest and craniofacial development, and neurogenesis. MEF2C mutations, deletions or duplications have been linked with human epilepsy syndromes, developmental or intellectual disabilities, autism, and cerebral malformations (reviewed in (Novara et al. 2013)). MEF2C deletions may also cause corpus callosum (47\%) and other cerebral abnormalities (84\%). MEF2C deletions cause infantile-onset epilepsy, expressive aphasia and developmental disabilities, strabismus, and bear some resemblance to Rett-like syndrome. At the other end of the spectrum, MEF2C duplication causes developmental disabilities and microcephaly.

MEF2C null mice lack the right ventricle of the heart (Lin et al. 1997), show vascular malformations (Bi et al. 1999) but die before birth. Conditional MEF2C knockout in nestinexpressing neural progenitors results in viable mice that have smaller size and aberrantly compacted neurons in the lower layers of the cerebral cortex, smaller brain size, and behavioral deficits ( $\mathrm{Li}$ et al. 2008). These included increased anxiety, paw wringing and clasping stereotypies, and spatial cognitive deficits ( $\mathrm{Li}$ et al. 2008). However no spontaneous seizures have yet been reported in these mice.

\section{MODELS STUDYING THE IMPACT OF SUBCLINICAL EPILEPTIFORM DISCHARGES ON BRAIN FUNCTION}

Among the most dramatic forms of epileptic encephalopathies in childhood are those manifesting with language, cognitive and/or behavioral regression in the setting of a very epileptic EEG. Landau Kleffner syndrome or acquired epileptic aphasia and the syndrome of continuous spike and waves in slow wave sleep (CSWS), with more global deterioration, are characteristic examples having as prominent feature the sleep related aggravation of epileptic activities 
(Galanopoulou et al. 2000; Tassinari et al. 1992). The short- and long-term effects of epileptiform discharges on brain function have been investigated in both clinical and animal studies.

Clinical studies have shown that transient focal or generalized epileptiform discharges may cause transitory cognitive impairment (Aarts et al. 1984; Binnie et al. 1987) or visual response delay or impairment in the presence of posterior spikes (Shewmon and Erwin 1988). Subclinical epileptiform discharges even shorter than half a second may also affect driving behavior (Kasteleijn-Nolst Trenite et al. 1987; Kasteleijn-Nolst Trenite and Vermeiren 2005). Epileptiform discharges are more deleterious when they occur within the $2 \mathrm{sec}$ prior to or coincident to the stimulus presentation (Binnie et al. 1987; Shewmon and Erwin 1988). The location of the discharges may determine the type of functional impairment. Left sided discharges affect verbal tasks and right sided impair spatial tasks whereas occipital spikes were more likely to influence response to visual stimuli. On the other hand, the type of task presented (topographical vs verbal vs driving) may affect the frequency of discharges further complicating the interpretation (Binnie et al. 1987; Kasteleijn-Nolst Trenite and Vermeiren 2005).

Studies in adult rats also demonstrated that hippocampal spikes may alter neuronal firing rates in a cell-type specific mode. Spontaneous hippocampal spikes a month following lithiumpilocarpine induced status epilepticus or 14 hours after 4-6 flurothyl seizures reduced the firing rates in hippocampal interneurons but not place cells (Zhou et al. 2007). Holmes and collaborators demonstrated the functional disruption caused by subclinical hippocampal spikes in adult rats. Electrical stimulation of the ventral hippocampal commissure produced hippocampal spikes without seizures in sleep only and resulted in prolonged times to reach the escape platform (Shatskikh et al. 2006). Spikes induced by intra-hippocampal pilocarpine impaired performance in delayed-match-to-sample task when spikes occurred during memory retrieval but not during memory encoding or maintenance (Kleen et al. 2010).

In developing animals, several studies have assessed the short term (after spike cessation) and long term effects of spikes. Short-term effects of spikes have been shown the day after spike cessation. Chow et al examined the impact of chronic epileptiform discharges in the visual system of the developing rabbit on the development and visual receptivity of neurons of the striate cortex and lateral geniculate body neurons (LGN). Chronic focal epileptiform discharges were generated in the LGN of rabbits that received twice daily focal infusions of penicillin, starting on PN6-8 and continuing for 19-14 days (Chow et al. 1978). A day after discontinuation of the infusions, and when epileptic discharges were not present, LGN recordings demonstrated significant disruption in the normal development of receptive fields. These disruptive effects of chronic epileptiform discharges were age-specific and not seen in adult rabbits (Baumbach and

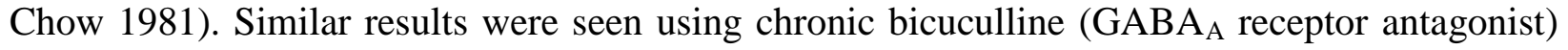
infusions in the monocular striate cortex from PN8-9 till either PN19-24 (for LGN recordings) or PN24-30 (for striatal neuron recordings) (Ostrach et al. 1984). In the bicuculline-infused striatal cortex, there was an abnormally high percentage of neurons showing no response and a parallel decrease in oriented cells.

Delayed or long-lasting effects of early life spikes may be documented in adulthood. In separate studies of developing male rats, spikes were induced with low doses of flurothyl given for 4 
hours over 10 days, starting at PN12, under EEG monitoring and performance in Morris water maze, four trial radial arm water maze and long-term potentiation was assessed in adulthood (Khan et al. 2010). Rats with early life flurothyl-induced spikes showed impaired reference memory and long-term potentiation. Repetitive bicuculline infusions in the prefrontal cortex of PN21-25 rats impaired attentiveness and social behavior in adulthood but had no effect on working memory, motivation, anxiety, or activity level (Hernan et al. 2014a). To test whether ACTH, which is currently used in the treatment of children with LKS or CSWS, improves outcomes, ACTH (Acthar gel, 150IU/m²) was given once daily 1 hour prior to the first daily bicuculline infusion between PN21-25 (Hernan et al. 2014b). ACTH ameliorated modestly the impaired attentiveness but had no effect on spikes or sociability.

These studies have provided model systems to demonstrate that subclinical spikes may have acute, short-term or long-term disruptive effects on specific brain functions but also that the specific task or experimental paradigm may affect the frequency of spikes. Furthermore, spike source / localization and frequency, laterality, and timing in reference to the studied function are important factors in determining the type and severity of impairment. However, a factor suggested by some of these studies and clinical experience, but not evaluated in depth so far, is the impact of background dysfunction on the short or long-term outcomes of spikes. Shewmon and Erwin suggested that the after-coming slow wave (surround hyperpolarization) may also disrupt cortical function (Shewmon and Erwin 1988) whereas the partial amelioration of attentiveness by ACTH pretreatment in adult rats with early life bicuculline-induced spikes seemed independent of any effect on spikes (Hernan et al. 2014b). Similarly, in most epileptic encephalopathies in humans, there is a degree of background slowing or dysfunction that could certainly contribute to the outcomes.

Dissociation between epileptiform discharges and cognitive dysfunction was also shown in a rat model of atypical absence seizures, the AY-9944 model (Chan et al. 2004; Cortez et al. 2001). Repetitive administration of AY-9944, a cholesterol biosynthesis inhibitor, in PN2, PN8, PN14, PN20 Long Evans hooded rats results in persisting appearance of recurrent, spontaneous atypical bursts of 4-6Hz slow spike wave discharges (SSWDs) (Cortez et al. 2001) and show impairment in spatial learning and working memory in the radial arm maze test (Chan et al. 2004). Abolishing the SSWDs with ethosuximide in AY-9944 rats failed to restore the performance of these rats. Conversely, low doses of the $\mathrm{GABA}_{\mathrm{B}}$ receptor inhibitor CGP35348 that did not affect SSWDs improve performance in the radial arm maze (Chan et al. 2006). These studies support that factors other than the acute presence of SSWDs or spikes may also underlie these cognitive deficits. These may include direct or indirect effects of the etiology (in humans) or induction method (in animal models), which may affect either the neurobiological processes or environmental factors that influence the cognitive and behavioral performance. For example, in developmental studies the induction method may prevent the dam to appropriately nurse the offspring which may have deleterious effects on its own. Similarly, in humans, it is difficult to dissociate the impact of the etiology of spikes or concurrent epilepsy or societal and environmental changes from the spike effects. The fact however that different modes of spike or epileptiform discharge induction or different etiologies in humans demonstrate similar effects corroborates the possibility that spikes may have adverse effects.

\section{CONCLUSIONS}


There is an increasing surge of animal models of early life epilepsies and epileptic encephalopathies that have provided useful tools for studying the role of specific pathogenic processes, the mechanisms through which certain known treatments work, or the identification of novel candidate therapies and target mechanisms, particularly for IS and Dravet syndrome. In genetic EIEE models the availability of mouse models of the specific genetic defects has allowed for the confirmation of the pathogenicity of these genes, or their relevance to the epilepsy or cognitive and neurodevelopmental deficits of the specific epilepsy syndrome. It has also become evident that strain and genetic substrate may modify the outcome, as is also known in humans. The value of these models for identifying and elucidating target mechanisms for epileptogenesis and epilepsy-related comorbidities is obvious. A classical example of a target-based therapy that emerged from animal studies and has been introduced in clinical studies is the use of mTOR inhibitors for epilepsy associated with tuberous sclerosis or mTOR-related genetic epilepsies (Cardamone et al. 2014; Krueger et al. 2013; Parker et al. 2013; Wiegand et al. 2013; Zeng et al. 2008).

How well may these animal models serve a major epilepsy benchmark, which is to successfully deliver new and more effective therapies in the clinical arena for early life epilepsies and epileptic encephalopathies, especially when there are so many species differences in biology, brain maturation and function, habitat and life style? Are these animal models of EIEEs validated and capable of de-risking therapy development for these usually medically refractory and devastating epilepsy syndromes? Currently, validation of animal models of EIEE can mostly rely on etiologic or phenotypic similarities to the human syndrome. Validation based on the response to specific therapies may be difficult for early life epilepsies. The rarity of many of these EIEEs has precluded large sample rigorous clinical studies and the reliable delineation of the panel of appropriate vs ineffective treatments, based on which one could validate these models. Even for syndromes with few known appropriate therapies, as in IS, there is still a significant percent of infants that are nonresponders from the start and for whom we still need to find effective treatments. The progress in animal models of EIEEs will therefore be invaluable in fulfilling these knowledge and treatment gaps. The recent and ongoing progress in yielding new candidate therapeutic targets and treatments using many of these animal models or IS or Dravet syndrome is certainly a ray of hope that the landscape may soon change.

\section{ACKNOWLEDGEMENTS}

ASG has received research funding from the US Department of Defense, NINDS NS078333, CURE, UCB, Johnson \& Johnson (carisbamate study), the Heffer Family and Barry Segal Family Foundations and the Abbe Goldstein/Joshua Lurie and Laurie Marsh/ Dan Levitz families. She has received royalties for book publishing from Morgan \& Claypool Publishers, honoraria from the Department of Defense (grant reviews), John Libbey Eurotext and Elsevier (publications). SLM is the Charles Frost Chair in Neurosurgery and Neurology and funded by grants from NIH NS043209, NS020253, NS045911, NS078333, CURE, US Department of Defense, UCB, Johnson \& Johnson (carisbamate study), from the Heffer Family and Barry Segal Family Foundations and the Abbe Goldstein/Joshua Lurie and Laurie Marsh/ Dan Levitz families. He receives from Elsevier an annual compensation for his work as Associate Editor in Neurobiology of Disease and royalties from 2 books he co-edited. He received a consultant fee from Lundbeck and UCB. SLM owns a patent for the multiple-hit model of IS (patent US7863499). There are no conflicts of interest related to this manuscript. 
Table 1. Models of epileptic spasms.

\begin{tabular}{|c|c|c|c|c|}
\hline \multicolumn{5}{|c|}{ Acute Models of epileptic spasms } \\
\hline & NMDA model & $\begin{array}{l}\text { Prenatal } \\
\text { betamethasone / } \\
\text { postnatal } \\
\text { NMDA }\end{array}$ & $\begin{array}{l}\text { Prenatal } \\
\text { stress / } \\
\text { postnatal } \\
\text { NMDA }\end{array}$ & Down / GBL \\
\hline References & 1 & 2 & 3 & 4 \\
\hline Method of induction & NMDA i.p. & $\begin{array}{l}\text { Betamethasone i.p. } \\
\text { (G15); NMDA i.p. } \\
\text { (PN12-15) }\end{array}$ & $\begin{array}{l}\text { Restraint stress } \\
\text { (G15); NMDA } \\
\text { i.p. (PN15) }\end{array}$ & GBL i.p. \\
\hline $\begin{array}{l}\text { Relevant pathogenic } \\
\text { mechanisms / } \\
\text { etiologies }\end{array}$ & $\begin{array}{l}\text { NMDA receptor } \\
\text { signaling is } \\
\text { involved in } \\
\text { expression of } \\
\text { spasms }\end{array}$ & \multicolumn{2}{|c|}{$\begin{array}{l}\text { Prenatal corticosteroids or stress } \\
\text { increase spasms severity and } \\
\text { augment their responsiveness to } \\
\text { ACTH }\end{array}$} & $\begin{array}{l}\text { GABA }_{B} \text { receptor } \\
\text { signaling is involved } \\
\text { in the expression of } \\
\text { spasms in Down } \\
\text { syndrome }\end{array}$ \\
\hline Species & Rats & Rats & Rats & Mice (Ts65Dn) \\
\hline $\begin{array}{l}\text { Age at spasms } \\
\text { induction }\end{array}$ & PN7-18 & PN12-15 & PN15 & 1 week -2 months \\
\hline Ictal EDR & Yes & Yes & N.R. & Yes \\
\hline Subsequent epilepsy & N.R. & N.R. & N.R. & N.R. \\
\hline $\begin{array}{l}\text { Response to ACTH } \\
\text { and/or vigabatrin }\end{array}$ & Yes & Yes & Yes & Yes \\
\hline $\begin{array}{l}\text { Behavioral / cognitive } \\
\text { sequelae }\end{array}$ & $\begin{array}{l}\text { Deficits in } \\
\text { learning and } \\
\text { coordination, } \\
\text { stereotypies }\end{array}$ & $\begin{array}{l}\text { Hyperactivity; } \\
\text { low anxiety (after } \\
\text { repetitive } \\
\text { induction of } \\
\text { NMDA spasms) }\end{array}$ & N.R. & $\begin{array}{l}\text { Not tested with GBL. } \\
\text { Deficits reported only } \\
\text { at the Ts65Dn mouse } \\
\text { model. }\end{array}$ \\
\hline \multicolumn{5}{|c|}{ Chronic Models of epileptic spasms } \\
\hline & TTX & ARX CKO & ARX KI & Multiple-Hit \\
\hline References & 5 & 6 & & 8 \\
\hline Method of induction & $\begin{array}{l}\text { Intrahippocampal } \\
\text { or intracortical } \\
\text { TTX infusion } \\
\text { (PN10-38) }\end{array}$ & $\begin{array}{l}\text { Targeted deletion } \\
\text { of ARX from } \\
\text { ganglionic } \\
\text { eminence }\end{array}$ & $\begin{array}{l}\text { Expansion of } \\
\text { first polyamine } \\
\text { tract repeat of } \\
\text { ARX }\end{array}$ & $\begin{array}{l}\text { Right intracerebral } \\
\text { doxorubicin and } \\
\text { lipopolysaccharide } \\
\text { (PN3); PCPA i.p. (PN5) }\end{array}$ \\
\hline $\begin{array}{l}\text { Relevant pathogenic } \\
\text { mechanisms / } \\
\text { etiologies }\end{array}$ & $\begin{array}{l}\text { Developmental } \\
\text { desynchronization } \\
\text { is involved in } \\
\text { expression of } \\
\text { spasms and } \\
\text { hypsarrhythmia }\end{array}$ & $\begin{array}{l}\text { ARX as genetic } \\
\text { etiology of } \\
\text { spasms }\end{array}$ & $\begin{array}{l}\text { ARX as } \\
\text { genetic } \\
\text { etiology of } \\
\text { spasms }\end{array}$ & $\begin{array}{l}\text { Structural and } \\
\text { inflammatory lesions } \\
\text { can trigger spasms } \\
\text { which are drug-resistant }\end{array}$ \\
\hline Species & Rats & Mice & Mice & Rats \\
\hline $\begin{array}{l}\text { Age at spasms } \\
\text { expression }\end{array}$ & PN21 - adulthood & Adulthood & PN7-20 & PN4-PN13 \\
\hline Ictal EDR & Yes & Yes & Yes & Yes \\
\hline Subsequent epilepsy & Yes & $\begin{array}{l}\text { Limbic seizures } \\
\text { (PN14-17) }\end{array}$ & $\begin{array}{l}\text { Yes }(3.5-10 \\
\text { weeks of age) }\end{array}$ & $\begin{array}{l}\text { Yes (after PN9 and in } \\
\text { adulthood) }\end{array}$ \\
\hline Testing with IS & N.R. & N.R. & N.R. & $\mathrm{ACTH}_{1-24}:$ No \\
\hline
\end{tabular}




\begin{tabular}{|c|c|c|c|}
\hline treatments & & & $\begin{array}{l}\text { Vigabatrin: Yes } \\
\text { (transient) }\end{array}$ \\
\hline $\begin{array}{l}\text { Behavioral / cognitive N.R. } \\
\text { sequelae }\end{array}$ & N.R. & $\begin{array}{l}\text { Low anxiety, } \\
\text { impaired } \\
\text { learning and } \\
\text { sociability }\end{array}$ & $\begin{array}{l}\text { Regression, impaired } \\
\text { learning and } \\
\text { sociability }\end{array}$ \\
\hline
\end{tabular}

EDR: electrodecremental response; G15: gestational day 15; GBL: $\gamma$-butyrolactone; N.R.: Not reported; PCPA: p-chlorophenylalanine; PN: postnatal day.

Reproduced from (Galanopoulou 2013) in a modified form with permission from Elsevier.

${ }^{1}$ (Kabova et al. 1999; Mares and Velisek 1992; Stafstrom and Sasaki-Adams 2003; Wang et al. 2012c)

${ }^{2}$ (Chachua et al. 2011; Velisek et al. 2007)

3 (Yum et al. 2012)

4 (Cortez et al. 2009)

${ }^{5}$ (Frost et al. 2011; Frost et al. 2012; Lee et al. 2008)

6 (Marsh et al. 2009)

7 (Olivetti and Noebels 2012; Price et al. 2009)

${ }^{8}$ (Akman et al. 2012; Briggs et al. 2014; Jequier Gygax et al. 2014; Ono et al. 2011; Raffo et al. 2011; Scantlebury et al. 2010) 
Table 2.

Preclinical drug testing in acute models of epileptic spasms: drugs given prior to induction of spasms.

\begin{tabular}{|c|c|c|c|c|}
\hline Drug & NMDA model & $\begin{array}{l}\text { Prenatal } \\
\text { betamethasone / } \\
\text { postnatal NMDA }\end{array}$ & $\begin{array}{l}\text { Prenatal } \\
\text { stress/postnatal } \\
\text { NMDA }\end{array}$ & Down / GBL \\
\hline $\mathrm{ACTH}_{1-24}$ & $\begin{array}{l}{ }^{1} \text { No effect on latency } \\
{[0.1-0.4 \mathrm{mg} / \mathrm{kg} \text { i.p. }]}\end{array}$ & & & $\begin{array}{l}\text { Shortens EDR } \\
{[40,80 \mu \mathrm{g} /} \\
\text { mouse }]\end{array}$ \\
\hline $\begin{array}{l}\text { ACTH }_{1-39} \\
\text { (Rat synthetic) }\end{array}$ & $\begin{array}{l}{ }^{1} \text { No effect on } \\
\text { latency }[0.1-0.4 \\
\text { mg/kg i.p.] }\end{array}$ & $\begin{array}{l}{ }^{1} \text { Delays spasms } \\
{[0.1 \mathrm{mg} / \mathrm{kg} \text { i.p.] }} \\
{ }^{7} \text { Reduces spasms in } \\
\text { PN15 rats } \\
{[0.3 \mathrm{mg} / \mathrm{kg} / \text { dose s.c.; }} \\
8 \text { total doses given on } \\
\text { PN12, PN13, PN14; } \\
\text { NMDA inj given } \\
\text { PN12, PN13, PN15] }\end{array}$ & $\begin{array}{l}{ }^{8} \text { No effect with } \\
\text { single dose. } \\
{ }^{8} \text { Delay and } \\
\text { reduction of } \\
\text { spasms after } 9 \\
\text { doses }[0.3 \\
\mathrm{mg} / \mathrm{kg} / \text { dose }, 3 \\
\text { doses/day s.c.] }\end{array}$ & \\
\hline $\begin{array}{l}\mathrm{ACTH}_{1-39} \\
\text { (porcine, } \\
\text { natural) }\end{array}$ & $\begin{array}{l}{ }^{2} \text { Delays and reduces } \\
\text { spasms severity on } \\
\text { PN11 [100 U/kg } \\
\text { ACTH i.p.] } \\
{ }^{3} \text { No effect on PN13 } \\
\text { [20 U/kg ACTH } \\
\text { i.p.] }\end{array}$ & & $\begin{array}{l}{ }^{3} \text { Delay and } \\
\text { reduction of } \\
\text { spasms on PN13 } \\
\text { [20 U/kg ACTH } \\
\text { i.p.] }\end{array}$ & $\begin{array}{l}{ }^{9} \text { No effect on } \\
\text { EDR duration } \\
{[20-80 \mu \mathrm{g} /} \\
\text { mouse] }\end{array}$ \\
\hline Hydrocortisone & $\begin{array}{l}{ }^{4} \text { Increases spasms } \\
{[10-25 \mathrm{mg} / \mathrm{kg}]}\end{array}$ & & & \\
\hline $\begin{array}{l}\text { Methylpredniso } \\
\text { lone }\end{array}$ & & $\begin{array}{l}{ }^{7} \text { Repetitive but not } \\
\text { single doses reduce } \\
\text { spasms incidence } \\
{[60 \mathrm{mg} / \mathrm{kg}]}\end{array}$ & & \\
\hline Vigabatrin & $\begin{array}{l}{ }^{5} \text { Decreased spasms } \\
\text { incidence }(600- \\
1200 \mathrm{mg} / \mathrm{kg})\end{array}$ & $\begin{array}{l}{ }^{7} \text { Decreases spasms } \\
\text { incidence } \\
(250 \mathrm{mg} / \mathrm{kg})\end{array}$ & & $\begin{array}{l}{ }^{9} \text { Shortens EDR } \\
(250-500 \mathrm{mg} / \mathrm{kg})\end{array}$ \\
\hline $\begin{array}{l}\text { Pyridoxine } \\
\text { (B6) }\end{array}$ & $\begin{array}{l}{ }^{4} \text { Decreases spasms } \\
\text { incidence; induces } \\
\text { epileptiform } \\
\text { activity }(250 \\
\mathrm{mg} / \mathrm{kg})\end{array}$ & & & \\
\hline Clonazepam & $\begin{array}{l}{ }^{6} \text { No effect }(0.2-1 \\
\mathrm{mg} / \mathrm{kg})\end{array}$ & & & \\
\hline Valproic acid & $\begin{array}{l}{ }^{5} \text { No effect }(100-400 \\
\mathrm{mg} / \mathrm{kg}) ; \\
{ }^{4} \text { Modest effect }\end{array}$ & & & $\begin{array}{l}{ }^{9} \text { Shortens EDR } \\
(100-400 \mathrm{mg} / \mathrm{kg})\end{array}$ \\
\hline Ethosuximide & & & & $\begin{array}{l}{ }^{9} \text { Shortens EDR } \\
(25-50 \mathrm{mg} / \mathrm{kg})\end{array}$ \\
\hline CGP 35348 & & & & ${ }^{9}$ Shortens EDR \\
\hline
\end{tabular}




\begin{tabular}{|c|c|c|}
\hline & & $(50-200 \mathrm{mg} / \mathrm{kg})$ \\
\hline Baclofen & & $\begin{array}{l}\text { Prolongs EDR } \\
(0.5-2 \mathrm{mg} / \mathrm{kg})\end{array}$ \\
\hline $\begin{array}{l}\text { 5-hydroxy- } \\
\text { tryptophan }\end{array}$ & & $\begin{array}{l}{ }^{9} \text { Prolongs EDR } \\
(100-150 \mathrm{mg} / \mathrm{kg})\end{array}$ \\
\hline Rapamycin & $\begin{array}{c}{ }^{7} \text { No acute effect } \\
\text { with low doses } \\
\text { [3 mg/kg i.p.] }\end{array}$ & \\
\hline Ganaxolone & $\begin{array}{l}{ }^{10} \text { No effect }(10 \mathrm{mg} / \mathrm{kg} \\
\text { i.p.) } \\
{ }^{10} \text { Reduces the number } \\
\text { and delays onset of } \\
\text { spasms (25-50 } \\
\text { mg/kg i.p.) }\end{array}$ & \\
\hline
\end{tabular}

Baclofen: $\mathrm{GABA}_{\mathrm{B}}$ receptor agonist; CGP 35348: $\mathrm{GABA}_{\mathrm{B}}$ receptor antagonist; GBL: $\gamma$ butyrolactone; EDR: electrodecremental response; i.p.: intraperitoneally; s.c.: subcutaneously; U: units.

Reproduced from (Galanopoulou 2013) in a modified form with permission from Elsevier.

1 (Velisek et al. 2007)

2 (Wang et al. 2012c)

3 (Wang et al. 2012b)

4 (Kabova et al. 1999)

5 (Kubova and Mares 2010)

${ }^{6}$ (Velisek and Mares 1995)

${ }^{7}$ (Chachua et al. 2011)

${ }^{8}$ (Yum et al. 2012)

9 (Cortez et al. 2009)

${ }^{10}$ (Yum et al. 2014) 
Table 3.

Preclinical drug testing studies in the chronic models.

\begin{tabular}{|c|c|c|c|}
\hline Drug & Protocol & Drug effect & References \\
\hline \multicolumn{4}{|c|}{$\begin{array}{l}\text { Multiple-hit rat model } \\
\text { (treatments tested after onset of spasms) }\end{array}$} \\
\hline $\mathrm{ACTH}_{1-24}$ & $\begin{array}{l}0.0125 \mathrm{mg} / \mathrm{kg} / \text { day i.p., } \\
\text { PN4-13 }\end{array}$ & No effect on spasms & $\begin{array}{l}\text { (Guerrini and } \\
\text { Filippi 2005; } \\
\text { Scantlebury et } \\
\text { al. 2010) }\end{array}$ \\
\hline $\begin{array}{l}\text { Vigabatrin } \\
\text { (GABA } \\
\text { aminotransferase } \\
\text { inactivator) }\end{array}$ & $\begin{array}{l}\text { 10-20 mg/kg i.p. } \\
\text { twice daily, } \\
\text { starting on PN4 }\end{array}$ & $\begin{array}{l}\text { Transient suppression of spasms on PN5; } \\
\text { higher doses were not tolerated }\end{array}$ & $\begin{array}{l}\text { (Scantlebury } \\
\text { et al. 2010) }\end{array}$ \\
\hline $\begin{array}{l}\text { CPP-115 (high } \\
\text { affinity } \\
\text { vigabatrin } \\
\text { analogue) } *\end{array}$ & $\begin{array}{l}\text { Single or daily } \\
\text { administration, } \\
\text { starting on PN4; } \\
0.1-1 \mathrm{mg} / \mathrm{kg} \text { i.p. }\end{array}$ & $\begin{array}{l}\text { Reduces spasms (PN5-7), no effect on } \\
\text { learning or neurodevelopmental milestones, } \\
\text { good tolerability; } \\
\text { Rapid onset effect on spasms on PN6-7 }\end{array}$ & $\begin{array}{l}\text { (Briggs et al. } \\
\text { 2014) }\end{array}$ \\
\hline Phenytoin & $\begin{array}{l}\text { Single injection } \\
\text { (PN4); } \\
20-50 \mathrm{mg} / \mathrm{kg} \text { i.p }\end{array}$ & No effect on spasms & $\begin{array}{l}\text { (Ono et al. } \\
\text { 2011) }\end{array}$ \\
\hline \multirow[t]{2}{*}{$\begin{array}{l}\text { Rapamycin } \\
\text { (mTOR inhibitor) }\end{array}$} & $\begin{array}{l}1-3 \mathrm{mg} / \mathrm{kg} \text { i.p. (PN4- } \\
12)\end{array}$ & No acute but delayed effect on spasms only. & \multirow[t]{2}{*}{$\begin{array}{l}\text { (Raffo et al. } \\
\text { 2011) }\end{array}$} \\
\hline & $\begin{array}{l}\text { Pulse protocol (i.p.): } \\
\text { PN4: } 6 \mathrm{mg} / \mathrm{kg} \\
\text { PN5: } 3 \mathrm{mg} / \mathrm{kg} \\
\text { PN6: } 3 \mathrm{mg} / \mathrm{kg}\end{array}$ & $\begin{array}{l}\text { Rapid onset reduction of spasms; } \\
\text { Stops spasms and improves Barnes maze } \\
\text { performance [PN16-19]. } \\
\text { No effect on other seizures till PN20. } \\
\text { Transient loss of weight during treatment } \\
\text { period. }\end{array}$ & \\
\hline Carisbamate * & $\begin{array}{l}\text { Single injection (PN4 } \\
\text { or PN6-7); } \\
30-60 \mathrm{mg} / \mathrm{kg} \text { i.p }\end{array}$ & $\begin{array}{l}\text { Acute suppression of behavioral and } \\
\text { electroclinical spasms during the acute } \\
\text { period (first 2-3 hours) }\end{array}$ & $\begin{array}{l}\text { (Ono et al. } \\
\text { 2011) }\end{array}$ \\
\hline $\begin{array}{l}\text { NAX } 5055 \\
\text { (galanin receptor } \\
1 \text { preferring } \\
\text { agonist) }\end{array}$ & $\begin{array}{l}\text { Single injection } \\
\text { (PN4); } \\
0.5-4 \mathrm{mg} / \mathrm{kg} \text { i.p. }\end{array}$ & $\begin{array}{l}\text { No effect on spasms; } \\
\text { but low expression of Galanin receptor } 1\end{array}$ & $\begin{array}{l}\text { (Jequier } \\
\text { Gygax et al. } \\
2014)\end{array}$ \\
\hline \multicolumn{4}{|c|}{$\begin{array}{l}\text { ARX KI mouse model } \\
\text { (treatment tested before onset of spasms) }\end{array}$} \\
\hline Estradiol & $\begin{array}{l}\text { 40ng/g s.c., } \\
\text { PN3-10 }\end{array}$ & $\begin{array}{l}\text { Prevents spasms and epilepsy, restores } \\
\text { interneuronal population in cerebral cortex. } \\
\text { PN33-40 treatment has no effect. }\end{array}$ & $\begin{array}{l}\text { (Olivetti et al. } \\
\text { 2014) }\end{array}$ \\
\hline
\end{tabular}

*: These drugs have acquired orphan drug indication for infantile spasms by FDA.

i.p.: intraperitoneal; s.c.: subcutaneous 
Table 4.

Animal models of SCN1A / SCN1B / SCN8A associated epilepsies

\begin{tabular}{|c|c|c|c|c|}
\hline Mouse model & $\begin{array}{l}\text { Genetic } \\
\text { defect }\end{array}$ & Phenotype & $\begin{array}{l}\text { Human } \\
\text { syndrome }\end{array}$ & Reference \\
\hline \multicolumn{5}{|l|}{ Mouse models } \\
\hline SCN1A KO & $\begin{array}{l}\text { Deletion of last } \\
\text { exon (domain } \\
\text { IV, S3-S6 } \\
\text { segment and C- } \\
\text { terminus) }\end{array}$ & $\begin{array}{l}\text { Heterozygous: } \\
\text { Thermal induced myoclonic and generalized } \\
\text { seizures (PN20-22, PN30-46); } \\
\text { Spontaneous seizures (>PN32); } \\
\text { Interictal spikes at normal temperature } \\
\text { (PN30-46) }\end{array}$ & Dravet & $\begin{array}{l}\text { (Kalume et } \\
\text { al. 2013; } \\
\text { Kalume et } \\
\text { al. 2007; } \\
\text { Oakley et al. } \\
\text { 2009; Yu et } \\
\text { al. 2006) }\end{array}$ \\
\hline SCN1A cKO & $\begin{array}{l}\text { Exon } 25 \\
\text { deletion, in } \\
\text { forebrain } \\
\text { GABAergic } \\
\text { interneurons }\end{array}$ & $\begin{array}{l}\text { Selective loss of Nav1.1 in forebrain cortical } \\
\text { and hippocampal GABAergic neurons; } \\
\text { Spontaneous seizures (stage 3-5, Racine); } \\
\text { Premature death after seizures (PN18-22); } \\
\text { Thermal induced seizures (PN22) }\end{array}$ & Dravet & $\begin{array}{l}\text { (Cheah et al. } \\
\text { 2012) }\end{array}$ \\
\hline $\begin{array}{l}\text { SCN1A KI, } \\
\text { R1407X }\end{array}$ & $\begin{array}{l}\text { R1407X } \\
\text { nonsense } \\
\text { mutation }\end{array}$ & $\begin{array}{l}\text { Heterozygous: } \\
\text { Low threshold in pentylenetetrazole seizures; } \\
\text { QT prolongation, ectopic ventricular foci, } \\
\text { idioventricular rhythms, beat-to-beat } \\
\text { variability, ventricular fibrillation, focal } \\
\text { bradycardia; } \\
23 \% \text { mortality } \\
\text { Heterozygous and homozygous: Spontaneous } \\
\text { seizures in } 1^{\text {st }} \text { postnatal month } \\
\text { Cardiac myocytes, heterozygous: } \\
\text { Increased excitability, action potential } \\
\text { duration }\end{array}$ & Dravet & $\begin{array}{l}\text { (Auerbach } \\
\text { et al. 2013; } \\
\text { Ogiwara et } \\
\text { al. 2007) }\end{array}$ \\
\hline SCN1A cKO & $\begin{array}{l}\text { Conditional } \\
\text { deletion of exon } \\
7\end{array}$ & $\begin{array}{l}\text { Deletion in global inhibitory neurons: } \\
\text { Heterozygous develop spontaneous seizures } \\
\text { (PN16) with occasional subsequent death. } \\
\text { Homozygous: PN10-15: hypoactivity, jerks; } \\
\text { death by PN15 } \\
\text { Deletion in forebrain excitatory neurons: } \\
\text { No spontaneous seizures } \\
\text { Deletion in forebrain excitatory neurons and } \\
\text { haploinsufficiency in inhibitory neurons: } \\
\text { Ameliorates seizure-related sudden death } \\
\text { Deletion in parvalbumin interneurons: } \\
\text { Homozygotes: Ataxia and spontaneous } \\
\text { seizures and ataxia (PN10 and PN14 } \\
\text { respectively; Death by PN30 } \\
\text { Heterozygotes: Spontaneous seizures and } \\
\text { death after PN16 }\end{array}$ & Dravet & $\begin{array}{l}\text { (Ogiwara et } \\
\text { al. 2013) }\end{array}$ \\
\hline $\begin{array}{l}\text { BAC transgene } \\
\text { with R1648H } \\
\text { mutation }\end{array}$ & $\begin{array}{l}\text { R1648H } \\
\text { mutation }\end{array}$ & $\begin{array}{l}\text { More severe kainic acid seizures } \\
\text { Cortical interneurons with slower recovery } \\
\text { from inactivation and increased use- } \\
\text { dependent Mate mkce of sodium channels }\end{array}$ & GEFS+ & $\begin{array}{l}\text { (Tang et al. } \\
\text { 2009) }\end{array}$ \\
\hline $\begin{array}{l}\text { SCN1A KI, } \\
\text { R1648H }\end{array}$ & $\begin{array}{l}\text { Human R1648H } \\
\text { mutation }\end{array}$ & $\begin{array}{l}\text { Homozygous: } \\
\text { Spontaneous generalized seizures (jump, } \\
\text { jerks, head nodding, clonus, hindlimb } \\
\text { extension); } \\
\text { Lower thresholds to hyperthermic or }\end{array}$ & GEFS+ & $\begin{array}{l}\text { (Martin et } \\
\text { al. 2010) }\end{array}$ \\
\hline
\end{tabular}




\begin{tabular}{|c|c|c|c|c|}
\hline & & $\begin{array}{l}\text { flurothyl seizures; } \\
\text { Premature death PN16-26; } \\
\text { Cortical interneurons with reduced firing, } \\
\text { slower recovery from inactivation and } \\
\text { increased use-dependent inactivation of } \\
\text { sodium channels. } \\
\text { Heterozygous: less severe phenotype than } \\
\text { homozygous. }\end{array}$ & & \\
\hline SCN1B KO & $\begin{array}{l}\text { SCN1B deletion } \\
\text { (both } \square 1 \text { and } \\
\square 1 \mathrm{~A} \text { isoforms) }\end{array}$ & $\begin{array}{l}\text { Homozygous: } \\
\text { Ataxia, spontaneous seizures, early } \\
\text { mortality. }\end{array}$ & Dravet & $\begin{array}{l}\text { (Chen et al. } \\
2004)\end{array}$ \\
\hline SCN1B KI, C121W & $\begin{array}{l}\text { Human C121W } \\
\text { SCN1B } \\
\text { mutation }\end{array}$ & $\begin{array}{l}\text { Homozygous: } \\
\text { Tremor, jerks, hunched back, poor weight } \\
\text { gain, early mortality; } \\
\text { Spontaneous seizures (stage } 1-6 \text {, Racine); } \\
\text { Thermal seizures; } \\
\text { Seizures respond to diazepam, stiripentol but } \\
\text { not to lamotrigine; } \\
\text { Thermal seizures respond to retigabine } \\
\text { Increased excitability of layer } 2 / 3 \text { pyramidal } \\
\text { neurons but no change in CA1 or Layer } 5 \\
\text { pyramidal neurons; } \\
\text { No change in GABAergic IPSCs in subicular } \\
\text { neurons; } \\
\text { Reduced arborization of neurons }\end{array}$ & Dravet & $\begin{array}{l}\text { (Reid et al. } \\
\text { 2014) }\end{array}$ \\
\hline $\begin{array}{l}\text { SCN8A KI, } \\
\text { N1768D }\end{array}$ & $\begin{array}{l}\text { Human SCN8A } \\
\text { N1768D } \\
\text { mutation }\end{array}$ & $\begin{array}{l}D / D \text { : tremor, ataxia, generalized clonic tonic } \\
\text { seizures, mortality (onset } 3 \text { weeks) } \\
D /-: \text { tremor, ataxia, generalized clonic tonic } \\
\text { seizures, mortality (onset } 3 \text { weeks) } \\
\text { D/+: seizures, no early mortality }\end{array}$ & & $\begin{array}{l}\text { (Wagnon et } \\
\text { al. 2015) }\end{array}$ \\
\hline \multicolumn{5}{|l|}{ Rat models } \\
\hline SCN1A N1417H & $\begin{array}{l}\text { N1417H } \\
\text { mutation (not } \\
\text { seen in humans) }\end{array}$ & $\begin{array}{l}5 \text { week old: } \\
\text { Increased grooming, hyperactivity, anxiety } \\
\text { like behavior, slower learning, less time on } \\
\text { rotarod, no spontaneous seizures. } \\
\text { Methylphenidate inhibits thermally induced } \\
\text { seizures. }\end{array}$ & & $\begin{array}{l}\text { (Ohmori et } \\
\text { al. 2014) }\end{array}$ \\
\hline \multicolumn{5}{|c|}{ Other animal models } \\
\hline $\begin{array}{l}\text { Scn1Lab } \\
\text { (zebrafish) }\end{array}$ & $\begin{array}{l}\text { Met to Arg } \\
\text { mutation in } \\
\text { domain III }\end{array}$ & $\begin{array}{l}\text { In vivo: increased swim activity, unprovoked } \\
\text { whole body convulsions and rapid } \\
\text { undirected movements } \\
\text { Extracellular field recordings in agar } \\
\text { immobilized larvae: seizure patterns; } \\
\text { hyperthermia induced seizures }\end{array}$ & Dravet & $\begin{array}{l}\text { (Baraban et } \\
\text { al. 2013) }\end{array}$ \\
\hline $\begin{array}{l}\text { SCN1A KI, } \\
\text { S1231R } \\
\text { (Drosophila) }\end{array}$ & $\begin{array}{l}\text { S1231R } \\
\text { mutation }\end{array}$ & $\begin{array}{l}\text { Spontaneous and thermal seizures; } \\
\text { Loss of function mutation: Reduced sodium } \\
\text { current activity and repetitive firing in } \\
\text { cortical interneurons }\end{array}$ & Dravet & $\begin{array}{l}\text { (Schutte et } \\
\text { al. 2014) }\end{array}$ \\
\hline $\begin{array}{l}\text { SCN1A KI, } \\
\text { K1270T } \\
\text { (Drosophila) }\end{array}$ & $\begin{array}{l}\text { K1270T } \\
\text { mutation }\end{array}$ & $\begin{array}{l}\text { Thermal seizures; } \\
\text { Gain of function mutation: Increased sodium } \\
\text { current conductive range than control }\end{array}$ & GEFS+ & $\begin{array}{l}\text { (Schutte et } \\
\text { al. 2014) }\end{array}$ \\
\hline
\end{tabular}

cKO: conditional knockout; GEFS+: Genetic Epilepsies with Febrile Seizures plus; KO: knockout; SCN: sodium channel. 


\section{REFERENCES}

Aarts JH, Binnie CD, Smit AM Wilkins AJ. "Selective cognitive impairment during focal and generalized epileptiform EEG activity." Brain 1984; 107 ( Pt 1): 293-308.

Akman O, Briggs SW Galanopoulou AS. "Long-term follow up of the multiple-hit model of symptomatic infantile spasms." Epilepsy Currents 2012; 13: 147.

Akman O, Moshe SL Galanopoulou AS. "Sex-specific consequences of early life seizures." Neurobiol Dis 2014; 72 Pt B: 153-166.

Amendola E, Zhan Y, Mattucci C, Castroflorio E, Calcagno E, Fuchs C, et al. "Mapping pathological phenotypes in a mouse model of CDKL5 disorder." PLoS One 2014; 9: e91613.

Auerbach DS, Jones J, Clawson BC, Offord J, Lenk GM, Ogiwara I, et al. "Altered cardiac electrophysiology and SUDEP in a model of Dravet syndrome." PLoS One 2013; 8: e77843.

Auvin S, Lamblin MD, Pandit F, Vallee L Bouvet-Mourcia A. "Infantile epileptic encephalopathy with late-onset spasms: report of 19 patients." Epilepsia 2010; 51: 12901296.

Avishai-Eliner S, Brunson KL, Sandman CA Baram TZ. "Stressed-out, or in (utero)?" Trends Neurosci 2002; 25: 518-524.

Baraban SC, Dinday MT Hortopan GA. "Drug screening in Scn1a zebrafish mutant identifies clemizole as a potential Dravet syndrome treatment." Nat Commun 2013; 4: 2410.

Baram TZ. "Pathophysiology of massive infantile spasms: perspective on the putative role of the brain adrenal axis." Ann Neurol 1993; 33: 231-236.

Baram TZ Lerner SP. "Ontogeny of corticotropin releasing hormone gene expression in rat hypothalamus--comparison with somatostatin." Int J Dev Neurosci 1991; 9: 473-478.

Baram TZ, Mitchell WG, Brunson K Haden E. "Infantile spasms: hypothesis-driven therapy and pilot human infant experiments using corticotropin-releasing hormone receptor antagonists." Dev Neurosci 1999; 21: 281-289.

Baram TZ, Mitchell WG, Snead OC, 3rd, Horton EJ Saito M. "Brain-adrenal axis hormones are altered in the CSF of infants with massive infantile spasms." Neurology 1992; 42: 11711175.

Baram TZ Schultz L. "Corticotropin-releasing hormone is a rapid and potent convulsant in the infant rat." Brain Res Dev Brain Res 1991; 61: 97-101.

Barcia G, Barnerias C, Rio M, Siquier-Pernet K, Desguerre I, Colleaux L, et al. "A novel mutation in STXBP1 causing epileptic encephalopathy (late onset infantile spasms) with partial respiratory chain complex IV deficiency." Eur J Med Genet 2013; 56: 683-685.

Barcia G, Chemaly N, Gobin S, Milh M, Van Bogaert P, Barnerias C, et al. "Early epileptic encephalopathies associated with STXBP1 mutations: Could we better delineate the phenotype?" Eur J Med Genet 2014; 57: 15-20.

Basel-Vanagaite L, Hershkovitz T, Heyman E, Raspall-Chaure M, Kakar N, Smirin-Yosef P, et al. "Biallelic SZT2 mutations cause infantile encephalopathy with epilepsy and dysmorphic corpus callosum." Am J Hum Genet 2013; 93: 524-529.

Baumbach HD Chow KL. "Visuocortical epileptiform discharges in rabbits: differential effects on neuronal development in the lateral geniculate nucleus and superior colliculus." Brain Res 1981; 209: 61-76. 
Beguin S, Crepel V, Aniksztejn L, Becq H, Pelosi B, Pallesi-Pocachard E, et al. "An epilepsyrelated ARX polyalanine expansion modifies glutamatergic neurons excitability and morphology without affecting GABAergic neurons development." Cereb Cortex 2013; 23: 1484-1494.

Berg AT, Berkovic SF, Brodie MJ, Buchhalter J, Cross JH, van Emde Boas W, et al. "Revised terminology and concepts for organization of seizures and epilepsies: report of the ILAE Commission on Classification and Terminology, 2005-2009." Epilepsia 2010; 51: 676685.

Best TK, Siarey RJ Galdzicki Z. "Ts65Dn, a mouse model of Down syndrome, exhibits increased GABAB-induced potassium current." J Neurophysiol 2007; 97: 892-900.

Bi W, Drake CJ Schwarz JJ. "The transcription factor MEF2C-null mouse exhibits complex vascular malformations and reduced cardiac expression of angiopoietin 1 and VEGF." Dev Biol 1999; 211: 255-267.

Binnie CD, Kasteleijn-Nolst Trenite DG, Smit AM Wilkins AJ. "Interactions of epileptiform EEG discharges and cognition." Epilepsy Res 1987; 1: 239-245.

Blanchard MG, Willemsen MH, Walker JB, Dib-Hajj SD, Waxman SG, Jongmans MC, et al. "De novo gain-of-function and loss-of-function mutations of SCN8A in patients with intellectual disabilities and epilepsy." J Med Genet 2015.

Bonneau D, Toutain A, Laquerriere A, Marret S, Saugier-Veber P, Barthez MA, et al. "X-linked lissencephaly with absent corpus callosum and ambiguous genitalia (XLAG): clinical, magnetic resonance imaging, and neuropathological findings." Ann Neurol 2002; 51: 340-349.

Boutry-Kryza N, Labalme A, Ville D, de Bellescize J, Touraine R, Prieur F, et al. "Molecular characterization of a cohort of 73 patients with infantile spasms syndrome." Eur J Med Genet 2015; 58: 51-58.

Briggs SW, Mowrey W, Hall CB Galanopoulou AS. "CPP-115, a vigabatrin analogue, decreases spasms in the multiple-hit rat model of infantile spasms." Epilepsia 2014; 55: 94-102.

Cao D, Ohtani H, Ogiwara I, Ohtani S, Takahashi Y, Yamakawa K, et al. "Efficacy of stiripentol in hyperthermia-induced seizures in a mouse model of Dravet syndrome." Epilepsia 2012; 53: 1140-1145.

Cardamone M, Flanagan D, Mowat D, Kennedy SE, Chopra M Lawson JA. "Mammalian target of rapamycin inhibitors for intractable epilepsy and subependymal giant cell astrocytomas in tuberous sclerosis complex." J Pediatr 2014; 164: 1195-1200.

Carvill GL, Heavin SB, Yendle SC, McMahon JM, O'Roak BJ, Cook J, et al. "Targeted resequencing in epileptic encephalopathies identifies de novo mutations in CHD2 and SYNGAP1." Nat Genet 2013; 45: 825-830.

Chachua T, Yum MS, Veliskova J Velisek L. "Validation of the rat model of cryptogenic infantile spasms." Epilepsia 2011; 52: 1666-1677.

Chan CH, Godinho LN, Thomaidou D, Tan SS, Gulisano M Parnavelas JG. "Emx1 is a marker for pyramidal neurons of the cerebral cortex." Cereb Cortex 2001; 11: 1191-1198.

Chan KF, Burnham WM, Jia Z, Cortez MA Snead OC, 3rd. "GABAB receptor antagonism abolishes the learning impairments in rats with chronic atypical absence seizures." Eur J Pharmacol 2006; 541: 64-72.

Chan KF, Jia Z, Murphy PA, Burnham WM, Cortez MA Snead OC, 3rd. "Learning and memory impairment in rats with chronic atypical absence seizures." Exp Neurol 2004; 190: 328336. 
Cheah CS, Yu FH, Westenbroek RE, Kalume FK, Oakley JC, Potter GB, et al. "Specific deletion of NaV1.1 sodium channels in inhibitory interneurons causes seizures and premature death in a mouse model of Dravet syndrome." Proc Natl Acad Sci U S A 2012; 109: 14646-14651.

Chen C, Westenbroek RE, Xu X, Edwards CA, Sorenson DR, Chen Y, et al. "Mice lacking sodium channel beta1 subunits display defects in neuronal excitability, sodium channel expression, and nodal architecture." J Neurosci 2004; 24: 4030-4042.

Chow KL, Baumbach HD Glanzman DL. "Abnormal development of lateral geniculate neurons in rabbit subjected to either eyelid closure or corticofugal paroxysmal discharges." Brain Res 1978; 146: 151-158.

Chu-Shore CJ, Major P, Camposano S, Muzykewicz D Thiele EA. "The natural history of epilepsy in tuberous sclerosis complex." Epilepsia 2010; 51: 1236-1241.

Claes L, Del-Favero J, Ceulemans B, Lagae L, Van Broeckhoven C De Jonghe P. "De novo mutations in the sodium-channel gene SCN1A cause severe myoclonic epilepsy of infancy." Am J Hum Genet 2001; 68: 1327-1332.

Clancy B, Darlington RB Finlay BL. "Translating developmental time across mammalian species." Neuroscience 2001; 105: 7-17.

Coleman M. "Infantile spasms associated with 5-hydroxytryptophan administration in patients with Down's syndrome." Neurology 1971; 21: 911-919.

Cortez MA, McKerlie C Snead OC, 3rd. "A model of atypical absence seizures: EEG, pharmacology, and developmental characterization." Neurology 2001; 56: 341-349.

Cortez MA, Shen L, Wu Y, Aleem IS, Trepanier CH, Sadeghnia HR, et al. "Infantile spasms and Down syndrome: a new animal model." Pediatr Res 2009; 65: 499-503.

Curatolo P, D'Argenzio L, Cerminara C Bombardieri R. "Management of epilepsy in tuberous sclerosis complex." Expert Rev Neurother 2008; 8: 457-467.

Dobbing J. "The later growth of the brain and its vulnerability." Pediatrics 1974; 53: 2-6.

Dobbing J Sands J. "Comparative aspects of the brain growth spurt." Early Hum Dev 1979; 3: 79-83.

Dobyns WB, Berry-Kravis E, Havernick NJ, Holden KR Viskochil D. "X-linked lissencephaly with absent corpus callosum and ambiguous genitalia." Am J Med Genet 1999; 86: 331337.

Dravet C Oguni H. "Dravet syndrome (severe myoclonic epilepsy in infancy)." Handb Clin Neurol 2013; 111: 627-633.

Dulac O, Bast T, Dalla Bernardina B, Gaily E Neville B. "Infantile spasms: toward a selective diagnostic and therapeutic approach." Epilepsia 2010; 51: 2218-2219; author reply 2221.

Dutton SB, Sawyer NT, Kalume F, Jumbo-Lucioni P, Borges K, Catterall WA, et al. "Protective effect of the ketogenic diet in Scn1a mutant mice." Epilepsia 2011; 52: 2050-2056.

Edvardson S, Baumann AM, Muhlenhoff M, Stephan O, Kuss AW, Shaag A, et al. "West syndrome caused by ST3Gal-III deficiency." Epilepsia 2013; 54: e24-27.

Epi4K. Consortium, Epilepsy Phenome/Genome Project, Allen AS, Berkovic SF, Cossette P, Delanty N, et al. "De novo mutations in epileptic encephalopathies." Nature 2013; 501: 217-221.

Escayg A Goldin AL. "Sodium channel SCN1A and epilepsy: mutations and mechanisms." Epilepsia 2010; 51: 1650-1658. 
Escayg A, MacDonald BT, Meisler MH, Baulac S, Huberfeld G, An-Gourfinkel I, et al. "Mutations of SCN1A, encoding a neuronal sodium channel, in two families with GEFS+2." Nat Genet 2000; 24: 343-345.

Estacion M, O'Brien JE, Conravey A, Hammer MF, Waxman SG, Dib-Hajj SD, et al. "A novel de novo mutation of SCN8A (Nav1.6) with enhanced channel activation in a child with epileptic encephalopathy." Neurobiol Dis 2014; 69: 117-123.

Euro Epinomics- R. E. S. Consortium, Epilepsy Phenome/Genome P Epi KC. "De novo mutations in synaptic transmission genes including DNM1 cause epileptic encephalopathies." Am J Hum Genet 2014; 95: 360-370.

Facchinetti F, Nalin A, Petraglia F, Galli V Genazzani AR. "Reduced ACTH, while normal betaendorphin CSF levels in early epileptic encephalopathies." Peptides 1985; 6: 31-33.

Falcone M, Yariz KO, Ross DB, Foster J, 2nd, Menendez I Tekin M. "An amino acid deletion inSZT2 in a family with non-syndromic intellectual disability." PLoS One 2013; 8: e82810.

Frankel WN, Yang Y, Mahaffey CL, Beyer BJ O'Brien TP. "Szt2, a novel gene for seizure threshold in mice." Genes Brain Behav 2009; 8: 568-576.

Friocourt G Parnavelas JG. "Mutations in ARX Result in Several Defects Involving GABAergic Neurons." Front Cell Neurosci 2010; 4: 4.

Frost JD, Jr. Hrachovy RA. "Pathogenesis of infantile spasms: a model based on developmental desynchronization." J Clin Neurophysiol 2005; 22: 25-36.

Frost JD, Jr., Lee CL, Hrachovy RA Swann JW. "High frequency EEG activity associated with ictal events in an animal model of infantile spasms." Epilepsia 2011; 52: 53-62.

Frost JD, Jr., Lee CL, Le JT, Hrachovy RA Swann JW. "Interictal high frequency oscillations in an animal model of infantile spasms." Neurobiol Dis 2012; 46: 377-388.

Fujiwara T, Sugawara T, Mazaki-Miyazaki E, Takahashi Y, Fukushima K, Watanabe M, et al. "Mutations of sodium channel alpha subunit type 1 (SCN1A) in intractable childhood epilepsies with frequent generalized tonic-clonic seizures." Brain 2003; 126: 531-546.

Galanopoulou AS. "Basic mechanisms of catastrophic epilepsy -- overview from animal models." Brain Dev 2013; 35: 748-756.

Galanopoulou AS, Bojko A, Lado F Moshe SL. "The spectrum of neuropsychiatric abnormalities associated with electrical status epilepticus in sleep." Brain Dev 2000; 22: 279-295.

Galanopoulou AS, Gorter JA Cepeda C. "Finding a better drug for epilepsy: the mTOR pathway as an antiepileptogenic target." Epilepsia 2012; 53: 1119-1130.

Galanopoulou AS Moshe SL. "In search of epilepsy biomarkers in the immature brain: goals, challenges and strategies." Biomark Med 2011; 5: 615-628.

Gheyara AL, Ponnusamy R, Djukic B, Craft RJ, Ho K, Guo W, et al. "Tau reduction prevents disease in a mouse model of Dravet syndrome." Ann Neurol 2014; 76: 443-456.

Go CY, Mackay MT, Weiss SK, Stephens D, Adams-Webber T, Ashwal S, et al. "Evidencebased guideline update: medical treatment of infantile spasms. Report of the Guideline Development Subcommittee of the American Academy of Neurology and the Practice Committee of the Child Neurology Society." Neurology 2012; 78: 1974-1980.

Goldberg-Stern H, Strawsburg RH, Patterson B, Hickey F, Bare M, Gadoth N, et al. "Seizure frequency and characteristics in children with Down syndrome." Brain Dev 2001; 23: 375-378.

Gottlieb A, Keydar I Epstein HT. "Rodent brain growth stages: an analytical review." Biol Neonate 1977; 32: 166-176. 
Guerrini R Filippi T. "Neuronal migration disorders, genetics, and epileptogenesis." J Child Neurol 2005; 20: 287-299.

Hager T, Maroteaux G, Pont P, Julsing J, van Vliet R Stiedl O. "Munc18-1 haploinsufficiency results in enhanced anxiety-like behavior as determined by heart rate responses in mice." Behav Brain Res 2014; 260: 44-52.

Han S, Tai C, Westenbroek RE, Yu FH, Cheah CS, Potter GB, et al. "Autistic-like behaviour in Scn1a+/- mice and rescue by enhanced GABA-mediated neurotransmission." Nature 2012; 489: 385-390.

Heiskala H. "CSF ACTH and beta-endorphin in infants with West syndrome and ACTH therapy." Brain Dev 1997; 19: 339-342.

Hernan AE, Alexander A, Jenks KR, Barry J, Lenck-Santini PP, Isaeva E, et al. "Focal epileptiform activity in the prefrontal cortex is associated with long-term attention and sociability deficits." Neurobiol Dis 2014a; 63: 25-34.

Hernan AE, Alexander A, Lenck-Santini PP, Scott RC Holmes GL. "Attention deficit associated with early life interictal spikes in a rat model is improved with ACTH." PLoS One 2014b; 9: e89812.

Hong AM, Turner Z, Hamdy RF Kossoff EH. "Infantile spasms treated with the ketogenic diet: prospective single-center experience in 104 consecutive infants." Epilepsia 2010; 51: 1403-1407.

Hrachovy RA, Frost JD, Jr. Kellaway P. "Hypsarrhythmia: variations on the theme." Epilepsia 1984; 25: 317-325.

Insel TR, Battaglia G, Fairbanks DW De Souza EB. "The ontogeny of brain receptors for corticotropin-releasing factor and the development of their functional association with adenylate cyclase." J Neurosci 1988; 8: 4151-4158.

Jequier Gygax M, Klein BD, White HS, Kim M Galanopoulou AS. "Efficacy and tolerability of the galanin analog NAX 5055 in the multiple-hit rat model of symptomatic infantile spasms." Epilepsy Res 2014; 108: 98-108.

Kabova R, Liptakova S, Slamberova R, Pometlova M Velisek L. "Age-specific N-methyl-Daspartate-induced seizures: perspectives for the West syndrome model." Epilepsia 1999; 40: 1357-1369.

Kalscheuer VM, Tao J, Donnelly A, Hollway G, Schwinger E, Kubart S, et al. "Disruption of the serine/threonine kinase 9 gene causes severe X-linked infantile spasms and mental retardation." Am J Hum Genet 2003; 72: 1401-1411.

Kalume F, Westenbroek RE, Cheah CS, Yu FH, Oakley JC, Scheuer T, et al. "Sudden unexpected death in a mouse model of Dravet syndrome." J Clin Invest 2013; 123: 17981808.

Kalume F, Yu FH, Westenbroek RE, Scheuer T Catterall WA. "Reduced sodium current in Purkinje neurons from Nav1.1 mutant mice: implications for ataxia in severe myoclonic epilepsy in infancy." J Neurosci 2007; 27: 11065-11074.

Kasteleijn-Nolst Trenite DG, Riemersma JB, Binnie CD, Smit AM Meinardi H. "The influence of subclinical epileptiform EEG discharges on driving behaviour." Electroencephalogr Clin Neurophysiol 1987; 67: 167-170.

Kasteleijn-Nolst Trenite DG Vermeiren R. "The impact of subclinical epileptiform discharges on complex tasks and cognition: relevance for aircrew and air traffic controllers." Epilepsy Behav 2005; 6: 31-34. 
Kato M, Das S, Petras K, Sawaishi Y Dobyns WB. "Polyalanine expansion of ARX associated with cryptogenic West syndrome." Neurology 2003; 61: 267-276.

Kato M Dobyns WB. "X-linked lissencephaly with abnormal genitalia as a tangential migration disorder causing intractable epilepsy: proposal for a new term, "interneuronopathy"." J Child Neurol 2005; 20: 392-397.

Kearney JA, Buchner DA, De Haan G, Adamska M, Levin SI, Furay AR, et al. "Molecular and pathological effects of a modifier gene on deficiency of the sodium channel Scn8a (Na(v)1.6)." Hum Mol Genet 2002; 11: 2765-2775.

Kehrl JM, Sahaya K, Dalton HM, Charbeneau RA, Kohut KT, Gilbert K, et al. "Gain-of-function mutation in Gnao1: a murine model of epileptiform encephalopathy (EIEE17)?" Mamm Genome 2014; 25: 202-210.

Kerrigan JF, Shields WD, Nelson TY, Bluestone DL, Dodson WE, Bourgeois BF, et al. "Ganaxolone for treating intractable infantile spasms: a multicenter, open-label, add-on trial." Epilepsy Res 2000; 42: 133-139.

Khan OI, Zhao Q, Miller F Holmes GL. "Interictal spikes in developing rats cause long-standing cognitive deficits." Neurobiol Dis 2010; 39: 362-371.

Kitamura K, Itou Y, Yanazawa M, Ohsawa M, Suzuki-Migishima R, Umeki Y, et al. "Three human ARX mutations cause the lissencephaly-like and mental retardation with epilepsylike pleiotropic phenotypes in mice." Hum Mol Genet 2009; 18: 3708-3724.

Kiwamoto T, Brummet ME, Wu F, Motari MG, Smith DF, Schnaar RL, et al. "Mice deficient in the St3gal3 gene product alpha2,3 sialyltransferase (ST3Gal-III) exhibit enhanced allergic eosinophilic airway inflammation." J Allergy Clin Immunol 2014; 133: 240-247 e241-243.

Kleen JK, Scott RC, Holmes GL Lenck-Santini PP. "Hippocampal interictal spikes disrupt cognition in rats." Ann Neurol 2010; 67: 250-257.

Krueger DA, Wilfong AA, Holland-Bouley K, Anderson AE, Agricola K, Tudor C, et al. "Everolimus treatment of refractory epilepsy in tuberous sclerosis complex." Ann Neurol 2013; 74: 679-687.

Kubova H Mares P. "Vigabatrin but not valproate prevents development of age-specific flexion seizures induced by N-methyl-D-aspartate (NMDA) in immature rats." Epilepsia 2010; 51: 469-472.

Kumar D Boehm U. "Genetic dissection of puberty in mice." Exp Physiol 2013; 98: 1528-1534.

Lado FA Moshe SL. "Role of subcortical structures in the pathogenesis of infantile spasms: what are possible subcortical mediators?" Int Rev Neurobiol 2002; 49: 115-140.

Langlais PJ, Wardlow ML Yamamoto H. "Changes in CSF neurotransmitters in infantile spasms." Pediatr Neurol 1991; 7: 440-445.

Lee CL, Frost JD, Jr., Swann JW Hrachovy RA. "A new animal model of infantile spasms with unprovoked persistent seizures." Epilepsia 2008; 49: 298-307.

Lemke JR, Hendrickx R, Geider K, Laube B, Schwake M, Harvey RJ, et al. "GRIN2B mutations in West syndrome and intellectual disability with focal epilepsy." Ann Neurol 2014; 75: 147-154.

Li H, Radford JC, Ragusa MJ, Shea KL, McKercher SR, Zaremba JD, et al. "Transcription factor MEF2C influences neural stem/progenitor cell differentiation and maturation in vivo." Proc Natl Acad Sci U S A 2008; 105: 9397-9402.

Lin Q, Schwarz J, Bucana C Olson EN. "Control of mouse cardiac morphogenesis and myogenesis by transcription factor MEF2C." Science 1997; 276: 1404-1407. 
Liptakova S, Velisek L, Veliskova J Moshe SL. "Effect of ganaxolone on flurothyl seizures in developing rats." Epilepsia 2000; 41: 788-793.

Lux AL, Edwards SW, Hancock E, Johnson AL, Kennedy CR, Newton RW, et al. "The United Kingdom Infantile Spasms Study (UKISS) comparing hormone treatment with vigabatrin on developmental and epilepsy outcomes to age 14 months: a multicentre randomised trial." Lancet Neurol 2005; 4: 712-717.

Mackay MT, Weiss SK, Adams-Webber T, Ashwal S, Stephens D, Ballaban-Gill K, et al. "Practice parameter: medical treatment of infantile spasms: report of the American Academy of Neurology and the Child Neurology Society." Neurology 2004; 62: 16681681.

Mares P Velisek L. "N-methyl-D-aspartate (NMDA)-induced seizures in developing rats." Brain Res Dev Brain Res 1992; 65: 185-189.

Mari F, Azimonti S, Bertani I, Bolognese F, Colombo E, Caselli R, et al. "CDKL5 belongs to the same molecular pathway of MeCP2 and it is responsible for the early-onset seizure variant of Rett syndrome." Hum Mol Genet 2005; 14: 1935-1946.

Marini C, Scheffer IE, Nabbout R, Suls A, De Jonghe P, Zara F, et al. "The genetics of Dravet syndrome." Epilepsia 2011; 52 Suppl 2: 24-29.

Marsh E, Fulp C, Gomez E, Nasrallah I, Minarcik J, Sudi J, et al. "Targeted loss of Arx results in a developmental epilepsy mouse model and recapitulates the human phenotype in heterozygous females." Brain 2009; 132: 1563-1576.

Martin MS, Dutt K, Papale LA, Dube CM, Dutton SB, de Haan G, et al. "Altered function of the SCN1A voltage-gated sodium channel leads to gamma-aminobutyric acid-ergic (GABAergic) interneuron abnormalities." J Biol Chem 2010; 285: 9823-9834.

Michaud JL, Lachance M, Hamdan FF, Carmant L, Lortie A, Diadori P, et al. "The genetic landscape of infantile spasms." Hum Mol Genet 2014; 23: 4846-4858.

Mistry AM, Thompson CH, Miller AR, Vanoye CG, George AL, Jr. Kearney JA. "Strain- and age-dependent hippocampal neuron sodium currents correlate with epilepsy severity in Dravet syndrome mice." Neurobiol Dis 2014; 65: 1-11.

Nabbout R. "A risk-benefit assessment of treatments for infantile spasms." Drug Saf 2001; 24 : $813-828$.

Nabbout R, Gennaro E, Dalla Bernardina B, Dulac O, Madia F, Bertini E, et al. "Spectrum of SCN1A mutations in severe myoclonic epilepsy of infancy." Neurology 2003; 60: 19611967.

Nagamitsu S, Matsuishi T, Yamashita Y, Shimizu T, Iwanaga R, Murakami Y, et al. "Decreased cerebrospinal fluid levels of beta-endorphin and ACTH in children with infantile spasms." J Neural Transm 2001; 108: 363-371.

Nakamura K, Kodera H, Akita T, Shiina M, Kato M, Hoshino H, et al. "De Novo mutations in GNAO1, encoding a Galphao subunit of heterotrimeric G proteins, cause epileptic encephalopathy." Am J Hum Genet 2013; 93: 496-505.

Nalin A, Facchinetti F, Galli V, Petraglia F, Storchi R Genazzani AR. "Reduced ACTH content in cerebrospinal fluid of children affected by cryptogenic infantile spasms with hypsarrhythmia." Epilepsia 1985; 26: 446-449.

Novara F, Rizzo A, Bedini G, Girgenti V, Esposito S, Pantaleoni C, et al. "MEF2C deletions and mutations versus duplications: a clinical comparison." Eur J Med Genet 2013; 56: 260265. 
Oakley JC, Cho AR, Cheah CS, Scheuer T Catterall WA. "Synergistic GABA-enhancing therapy against seizures in a mouse model of Dravet syndrome." J Pharmacol Exp Ther 2013; 345: 215-224.

Oakley JC, Kalume F, Yu FH, Scheuer T Catterall WA. "Temperature- and age-dependent seizures in a mouse model of severe myoclonic epilepsy in infancy." Proc Natl Acad Sci U S A 2009; 106: 3994-3999.

Ogiwara I, Iwasato T, Miyamoto H, Iwata R, Yamagata T, Mazaki E, et al. "Nav1.1 haploinsufficiency in excitatory neurons ameliorates seizure-associated sudden death in a mouse model of Dravet syndrome." Hum Mol Genet 2013; 22: 4784-4804.

Ogiwara I, Miyamoto H, Morita N, Atapour N, Mazaki E, Inoue I, et al. "Nav1.1 localizes to axons of parvalbumin-positive inhibitory interneurons: a circuit basis for epileptic seizures in mice carrying an Scn1a gene mutation." J Neurosci 2007; 27: 5903-5914.

Ohmori I, Kawakami N, Liu S, Wang H, Miyazaki I, Asanuma M, et al. "Methylphenidate improves learning impairments and hyperthermia-induced seizures caused by an Scn1a mutation." Epilepsia 2014; 55: 1558-1567.

Ohmori I, Ouchida M, Ohtsuka Y, Oka E Shimizu K. "Significant correlation of the SCN1A mutations and severe myoclonic epilepsy in infancy." Biochem Biophys Res Commun 2002; 295: 17-23.

Olivetti PR, Maheshwari A Noebels JL. "Neonatal estradiol stimulation prevents epilepsy in Arx model of X-linked infantile spasms syndrome." Sci Transl Med 2014; 6: 220ra212.

Olivetti PR Noebels JL. "Interneuron, interrupted: molecular pathogenesis of ARX mutations and X-linked infantile spasms." Curr Opin Neurobiol 2012; 22: 859-865.

Ono T, Moshe SL Galanopoulou AS. "Carisbamate acutely suppresses spasms in a rat model of symptomatic infantile spasms." Epilepsia 2011; 52: 1678-1684.

Orlova KA Crino PB. "The tuberous sclerosis complex." Ann N Y Acad Sci 2010; 1184: 87105.

Orlova KA, Parker WE, Heuer GG, Tsai V, Yoon J, Baybis M, et al. "STRADalpha deficiency results in aberrant mTORC1 signaling during corticogenesis in humans and mice." J Clin Invest 2010; 120: 1591-1602.

Ostrach LH, Crabtree JW, Campbell BG Chow KL. "Effects of bicuculline-induced epileptiform activity on development of receptive field properties in striate cortex and lateral geniculate nucleus of the rabbit." Brain Res 1984; 317: 113-123.

Pan Y, Gerasimov MR, Kvist T, Wellendorph P, Madsen KK, Pera E, et al. "(1S, 3S)-3-amino-4difluoromethylenyl-1-cyclopentanoic acid (CPP-115), a potent gamma-aminobutyric acid aminotransferase inactivator for the treatment of cocaine addiction." J Med Chem 2012; 55: 357-366.

Parker WE, Orlova KA, Parker WH, Birnbaum JF, Krymskaya VP, Goncharov DA, et al. "Rapamycin prevents seizures after depletion of STRADA in a rare neurodevelopmental disorder." Sci Transl Med 2013; 5: 182 ra153.

Patino GA, Claes LR, Lopez-Santiago LF, Slat EA, Dondeti RS, Chen C, et al. "A functional null mutation of SCN1B in a patient with Dravet syndrome." J Neurosci 2009; 29: 10764-10778.

Pellock JM, Hrachovy R, Shinnar S, Baram TZ, Bettis D, Dlugos DJ, et al. "Infantile spasms: a U.S. consensus report." Epilepsia 2010; 51: 2175-2189. 
Pires ME, Ilea A, Bourel E, Bellavoine V, Merdariu D, Berquin P, et al. "Ketogenic diet for infantile spasms refractory to first-line treatments: an open prospective study." Epilepsy Res 2013; 105: 189-194.

Poole AE Brain P. "Effects of adrenalectomy and treatments with ACTH and glucocorticoids on isolation-induced aggressive behavior in male albino mice." Prog Brain Res 1974; 41: 465-472.

Price MG, Yoo JW, Burgess DL, Deng F, Hrachovy RA, Frost JD, Jr., et al. "A triplet repeat expansion genetic mouse model of infantile spasms syndrome, $\operatorname{Arx}(\mathrm{GCG}) 10+7$, with interneuronopathy, spasms in infancy, persistent seizures, and adult cognitive and behavioral impairment." J Neurosci 2009; 29: 8752-8763.

Pueschel SM, Louis S McKnight P. "Seizure disorders in Down syndrome." Arch Neurol 1991; 48: 318-320.

Raffo E, Coppola A, Ono T, Briggs SW Galanopoulou AS. "A pulse rapamycin therapy for infantile spasms and associated cognitive decline." Neurobiol Dis 2011; 43: 322-329.

Reid CA, Leaw B, Richards KL, Richardson R, Wimmer V, Yu C, et al. "Reduced dendritic arborization and hyperexcitability of pyramidal neurons in a Scn1b-based model of Dravet syndrome." Brain 2014; 137: 1701-1715.

Riikonen R. "Infantile spasms: some new theoretical aspects." Epilepsia 1983; 24: 159-168.

Riikonen R. "Recent advances in the pharmacotherapy of infantile spasms." CNS Drugs 2014; 28: 279-290.

Romano C, Tine A, Fazio G, Rizzo R, Colognola RM, Sorge G, et al. "Seizures in patients with trisomy 21." Am J Med Genet Suppl 1990; 7: 298-300.

Saitsu H, Kato M, Okada I, Orii KE, Higuchi T, Hoshino H, et al. "STXBP1 mutations in early infantile epileptic encephalopathy with suppression-burst pattern." Epilepsia 2010; 51: 2397-2405.

Sanmaneechai O, Sogawa Y, Silver W, Ballaban-Gil K, Moshe SL Shinnar S. "Treatment outcomes of West syndrome in infants with Down syndrome." Pediatr Neurol 2013; 48: 42-47.

Scala E, Ariani F, Mari F, Caselli R, Pescucci C, Longo I, et al. "CDKL5/STK9 is mutated in Rett syndrome variant with infantile spasms." J Med Genet 2005; 42: 103-107.

Scantlebury MH, Galanopoulou AS, Chudomelova L, Raffo E, Betancourth D Moshe SL. "A model of symptomatic infantile spasms syndrome." Neurobiol Dis 2010; 37: 604-612.

Schneider M. "Adolescence as a vulnerable period to alter rodent behavior." Cell Tissue Res 2013; 354: 99-106.

Schutte RJ, Schutte SS, Algara J, Barragan EV, Gilligan J, Staber C, et al. "Knock-in model of Dravet Syndrome reveals a constitutive and conditional reduction in sodium current." J Neurophysiol 2014; 112: 903-912.

Shatskikh TN, Raghavendra M, Zhao Q, Cui Z Holmes GL. "Electrical induction of spikes in the hippocampus impairs recognition capacity and spatial memory in rats." Epilepsy Behav 2006; 9: 549-556.

Shewmon DA Erwin RJ. "Focal spike-induced cerebral dysfunction is related to the after-coming slow wave." Ann Neurol 1988; 23: 131-137.

Shi XY, Zou LP, Yang G Ding YX. "Prenatal stress exposure hypothesis for infantile spasms." Med Hypotheses 2012; 78: 735-737.

Silverman RB. "The 2011 E. B. Hershberg award for important discoveries in medicinally active substances: (1S,3S)-3-amino-4-difluoromethylenyl-1-cyclopentanoic acid (CPP-115), a 
GABA aminotransferase inactivator and new treatment for drug addiction and infantile spasms." J Med Chem 2012; 55: 567-575.

Silverstein F Johnston MV. "Cerebrospinal fluid monoamine metabolites in patients with infantile spasms." Neurology 1984; 34: 102-105.

Simonet JC, Sunnen CN, Wu J, Golden JA Marsh ED. "Conditional Loss of Arx From the Developing Dorsal Telencephalon Results in Behavioral Phenotypes Resembling Mild Human ARX Mutations." Cereb Cortex 2014: [Epub ahead of print].

Sprunger LK, Escayg A, Tallaksen-Greene S, Albin RL Meisler MH. "Dystonia associated with mutation of the neuronal sodium channel $S \mathrm{cn} 8 \mathrm{a}$ and identification of the modifier locus Scnm1 on mouse chromosome 3." Hum Mol Genet 1999; 8: 471-479.

Stafstrom CE, Moshe SL, Swann JW, Nehlig A, Jacobs MP Schwartzkroin PA. "Models of pediatric epilepsies: strategies and opportunities." Epilepsia 2006; 47: 1407-1414.

Stafstrom CE Sasaki-Adams DM. "NMDA-induced seizures in developing rats cause long-term learning impairment and increased seizure susceptibility." Epilepsy Res 2003; 53: 129137.

Stromme P, Mangelsdorf ME, Shaw MA, Lower KM, Lewis SM, Bruyere H, et al. "Mutations in the human ortholog of Aristaless cause X-linked mental retardation and epilepsy." Nat Genet 2002; 30: 441-445.

Sturgill ER, Aoki K, Lopez PH, Colacurcio D, Vajn K, Lorenzini I, et al. "Biosynthesis of the major brain gangliosides GD1a and GT1b." Glycobiology 2012; 22: 1289-1301.

Sugawara T, Mazaki-Miyazaki E, Fukushima K, Shimomura J, Fujiwara T, Hamano S, et al. "Frequent mutations of SCN1A in severe myoclonic epilepsy in infancy." Neurology 2002; 58: 1122-1124.

Tang B, Dutt K, Papale L, Rusconi R, Shankar A, Hunter J, et al. "A BAC transgenic mouse model reveals neuron subtype-specific effects of a Generalized Epilepsy with Febrile Seizures Plus (GEFS+) mutation." Neurobiol Dis 2009; 35: 91-102.

Tassinari CA, Michelucci R, Forti A, Salvi F, Plasmati R, Rubboli G, et al. "The electrical status epilepticus syndrome." Epilepsy Res Suppl 1992; 6: 111-115.

Thiele EA. "Managing epilepsy in tuberous sclerosis complex." J Child Neurol 2004; 19: 680686.

Veeramah KR, O'Brien JE, Meisler MH, Cheng X, Dib-Hajj SD, Waxman SG, et al. "De novo pathogenic SCN8A mutation identified by whole-genome sequencing of a family quartet affected by infantile epileptic encephalopathy and SUDEP." Am J Hum Genet 2012; 90 : 502-510.

Velisek L, Jehle K, Asche S Veliskova J. "Model of infantile spasms induced by N-methyl-Daspartic acid in prenatally impaired brain." Ann Neurol 2007; 61: 109-119.

Velisek L Mares P. "Age-dependent anticonvulsant action of clonazepam in the N-methyl-Daspartate model of seizures." Pharmacol Biochem Behav 1995; 52: 291-296.

Wagnon JL, Korn MJ, Parent R, Tarpey TA, Jones JM, Hammer MF, et al. "Convulsive seizures and SUDEP in a mouse model of SCN8A epileptic encephalopathy." Hum Mol Genet 2015; 24: 506-515.

Wang IT, Allen M, Goffin D, Zhu X, Fairless AH, Brodkin ES, et al. "Loss of CDKL5 disrupts kinome profile and event-related potentials leading to autistic-like phenotypes in mice." Proc Natl Acad Sci U S A 2012a; 109: 21516-21521. 
Wang J, Wang J, Zhang Y, Yang G, Zhou WJ, Shang AJ, et al. "Proteomic analysis of adrenocorticotropic hormone treatment of an infantile spasm model induced by Nmethyl-D-aspartic acid and prenatal stress." PLoS One 2012b; 7: e45347.

Wang YJ, Zhang Y, Liang XH, Yang G Zou LP. "Effects of adrenal dysfunction and high-dose adrenocorticotropic hormone on NMDA-induced spasm seizures in young Wistar rats." Epilepsy Res 2012c; 100: 125-131.

Watanabe H, Nagata E, Kosakai A, Nakamura M, Yokoyama M, Tanaka K, et al. "Disruption of the epilepsy KCNQ2 gene results in neural hyperexcitability." J Neurochem 2000; 75: 28-33.

Weaving LS, Christodoulou J, Williamson SL, Friend KL, McKenzie OL, Archer H, et al. "Mutations of CDKL5 cause a severe neurodevelopmental disorder with infantile spasms and mental retardation." Am J Hum Genet 2004; 75: 1079-1093.

West WJ. "On a peculiar form of infantile convulsions." Lancet Neurol 1841; 1: 724-725.

Wiegand G, May TW, Ostertag P, Boor R, Stephani U Franz DN. "Everolimus in tuberous sclerosis patients with intractable epilepsy: a treatment option?" Eur J Paediatr Neurol 2013; 17: 631-638.

Willig RP, Lagenstein I Iffland E. "[Circadian rhythm of cortisol under ACTH and dexamethasone therapy of convulsions in early childhood (BNS- and Lennox-syndrome) (author's transl)]." Monatsschr Kinderheilkd 1978; 126: 191-197.

Yamamoto H. "Studies on CSF tryptophan metabolism in infantile spasms." Pediatr Neurol 1991; 7: 411-414.

Yang Y, Beyer BJ, Otto JF, O'Brien TP, Letts VA, White HS, et al. "Spontaneous deletion of epilepsy gene orthologs in a mutant mouse with a low electroconvulsive threshold." Hum Mol Genet 2003; 12: 975-984.

Yu FH, Mantegazza M, Westenbroek RE, Robbins CA, Kalume F, Burton KA, et al. "Reduced sodium current in GABAergic interneurons in a mouse model of severe myoclonic epilepsy in infancy." Nat Neurosci 2006; 9: 1142-1149.

Yum MS, Chachua T, Veliskova J Velisek L. "Prenatal stress promotes development of spasms in infant rats." Epilepsia 2012; 53: e46-49.

Yum MS, Lee M, Ko TS Velisek L. "A potential effect of ganaxolone in an animal model of infantile spasms." Epilepsy Res 2014; 108: 1492-1500.

Zeng LH, Xu L, Gutmann DH Wong M. "Rapamycin prevents epilepsy in a mouse model of tuberous sclerosis complex." Ann Neurol 2008; 63: 444-453.

Zhou JL, Lenck-Santini PP, Zhao Q Holmes GL. "Effect of interictal spikes on single-cell firing patterns in the hippocampus." Epilepsia 2007; 48: 720-731. 